Atmos. Chem. Phys., 10, 817-842, 2010

www.atmos-chem-phys.net/10/817/2010/

(C) Author(s) 2010. This work is distributed under

the Creative Commons Attribution 3.0 License.

\title{
A meteorological overview of the ARCTAS 2008 mission
}

\author{
H. E. Fuelberg, D. L. Harrigan, and W. Sessions \\ Department of Meteorology, Florida State University, Tallahassee, FL, USA
}

Received: 14 August 2009 - Published in Atmos. Chem. Phys. Discuss.: 4 September 2009

Revised: 24 December 2009 - Accepted: 7 January 2010 - Published: 26 January 2010

\begin{abstract}
The Arctic Research of the Composition of the Troposphere from Aircraft and Satellites (ARCTAS) mission was a multi-aircraft project whose major objective was to investigate the factors driving changes in the Arctic's atmospheric composition and climate. It was conducted during April and June-July 2008. The summer ARCTAS deployment was preceded by a week of flights over and around California to address state issues of air quality and climate forcing. This paper focuses on meteorological conditions during the ARCTAS Spring and Summer campaigns. We examine mission averaged large-scale flow patterns at the surface, $500 \mathrm{hPa}$, and $300 \mathrm{hPa}$ and determine their departures from climatology. Results from runs of the Weather Research and $F$ orecasting (WRF) model are used to describe meteorological conditions on individual days. Our WRF configuration included a nested grid approach that provided horizontal spacing as small as $5 \mathrm{~km}$. Trajectories calculated from the WRF output are used to determine transport pathways to the Arctic, including their origins and the altitudes at which they reach $70^{\circ} \mathrm{N}$. We also present backward trajectories from selected legs of individual ARCTAS flights. Finally, the FLEXPART Lagrangian particle dispersion model, with the high resolution WRF data as input, is used to determine the paths of anthropogenic and biomass burning-derived CO. Results show that there was frequent and widespread transport to the Arctic during both phases of ARCTAS and that the three ARCTAS aircraft sampled air having a multitude of origins, following a myriad of paths, and experiencing many types of meteorological conditions.
\end{abstract}

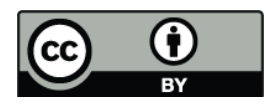

Correspondence to: H. E. Fuelberg (fuelberg@met.fsu.edu)

\section{Introduction}

The Arctic Research of the Composition of the Troposphere from Aircraft and Satellites (ARCTAS) mission was conducted during April and June-July 2008 by the Global Tropospheric Chemistry and the Radiation Sciences Programs of the US National Aeronautics and Space Administration (NASA) (Jacob et al., 2009). The European community conducted a companion project called Polar Study using Aircraft, Remote Sensing, Surface Measurements and Models, of Climate, Chemistry, Aerosols, and Transport (POLARCAT, Stohl and Law, 2006). ARCTAS was a multi-aircraft project whose major objective was to investigate the factors driving changes in the Arctic's atmospheric composition and climate. The project was organized around four main research themes: 1) long-range transport of pollution to the Arctic, 2) boreal forest fires, 3) aerosol radiative properties, and 4) ozone budget and chemical processes. The summer ARCTAS deployment was preceded by a week of flights over and around California to address state issues of air quality and climate forcing. The current paper focuses on theme 1) - meteorological conditions influencing long range transport to the Arctic.

Meteorological factors play a major role in determining pollutant transport to the Arctic. Once a pollutant is released into the atmosphere, the winds transport it both horizontally and vertically, and the pollutant may undergo chemical transformations such as oxidation of hydrocarbons by $\mathrm{OH}$, and be subjected to depletion processes such as particle scavenging, dry or wet deposition, and turbulent processes and mixing which dilute or mix polluted plumes and affect their chemistry.

Several important meteorological concepts are applicable to the Arctic. First, the Arctic is characterized by strong surface-based temperature inversions that limit turbulent mixing and vertical transport (Curry, 1983, 1987; Raatz, 1991; Bradley et al. 1992). The inversions are most

Published by Copernicus Publications on behalf of the European Geosciences Union. 
prominent during winter when there is little or no sunlight and snow cover is most widespread. Winter also is the time when the air is driest, leading to the least amount of wet deposition of aerosols (Shaw, 1995). A second important concept is the orientation of potential temperature (isentropic) surfaces between the tropics and the Arctic, i.e., they increase with altitude and curve upward toward the North Pole (Carlson, 1981; Iversen 1984; Raatz 1991). Since air parcels conserve their potential temperature in the absence of diabatic processes such as sensible heating or cooling, condensation, freezing, and radiative processes, adiabatic flow requires that low level middle latitude parcels ascend as they approach the Arctic. This quasi-isentropic ascent may explain elevated Arctic haze layers (Klonecki et al. 2003; Shaw, 1995). However, if middle latitude air is to remain at low altitudes, it must undergo considerable diabatic cooling that can occur when air passes over a snow covered surface for an extended period, e.g., passing over Northern Eurasia (e.g., Raatz, 1991). The upward slope of isentropes toward the pole is not as strong during summer. A third major concept is the Arctic front which separates the coldest Arctic air from warmer air to the south. The frontal location varies on a daily basis but can reach as far south as $40^{\circ} \mathrm{N}$ during the coldest periods (Barrie, 1986). Since the Arctic front is a zone of strong isentropic gradient, it has been characterized as a barrier to the poleward transport of pollution due to the quasi-isentropic processes described above (Stohl, 2006; Klonecki et al., 2003). Finally, middle latitude cyclones influence Arctic meteorology. Although surface cyclone centers seldom reach the North Pole, their warm conveyor belts (WCBs) can lift low level air into the upper troposphere where it can be transported northward to the high Arctic (Eckhardt et al., 2004, Stohl, 2006).

This paper focuses on the meteorological settings during the ARCTAS Spring and Summer campaigns (denoted ARCTAS-A and B, respectively), including large-scale flow patterns, their departures from climatology, distributions of lightning and wildfires, transport pathways to the Arctic, and the origins and paths taken by air sampled by the ARCTAS aircraft. Longer term Arctic transport studies have been presented by Stohl (2006), Klonecki et al. (2003), and Eckhardt et al. 2003). Our goal is to assess the representativeness of the ARCTAS period with respect to climatological conditions, quantify certain aspects of Arctic transport, and present examples of transport that occurred during the mission.

\section{Data and methodology}

\subsection{Numerical simulations}

Means of meteorological quantities during the ARCTAS period, long term climatologies, as well as departures from climatology, were obtained using re-analysis data prepared by the National Centers for Environmental Prediction (NCEP)
(Kalnay et al., 1996). The data and viewing software are available on the web site of the NOAA-CIRES Climate Diagnostics Center (CDC) at http://www.cdc.noaa.gov.

The meteorological data used to prepare daily analyses, trajectories, and FLEXPART Lagrangian particle dispersion runs were obtained using the Weather Research and Forecasting (WRF) numerical model (Skamarock et al., 2008) at Florida State University (FSU). Our baseline WRF computational area (Fig. 1) consisted of an outer domain with a $45 \mathrm{~km}$ grid spacing that spanned much of the Northern Hemisphere. Two nested inner grids of $15 \mathrm{~km}$ and $5 \mathrm{~km}$, each with a two way transfer of information, were located within the larger domain. Their locations changed between the spring and summer phases of ARCTAS to account for the changing areas of anthropogenic and biomass burning emissions (Fig. 1a, b). Each of the three domains contained 50 vertical levels that were most tightly packed in the boundary layer (average vertical spacing $\sim 15 \mathrm{hPa}$ ) and near the tropopause (average vertical space $\sim 18 \mathrm{hPa}$ ). Our WRF runs began at 12:00 UTC each day and continued for $36 \mathrm{~h}$, with the first $12 \mathrm{~h}$ of each run considered a model "spin up" period whose data were not used. The WRF runs utilized four dimensional data assimilation from the National Weather Service's Global Forecast System (GFS) during the first $12 \mathrm{~h}$ of each $36 \mathrm{~h}$ daily run. The remaining $24 \mathrm{~h}$ of data for each run were archived at hourly intervals for later calculations.

Version 3.0.1.1 of the Advanced Research WRF (ARW) (Skamarock et al., 2008) is a fully compressible, nonhydrostatic mesoscale model integrated on the Arakawa Cgrid and terrain-following hydrostatic pressure coordinates. WRF uses the Runge-Kutta 2nd and 3rd order time integration schemes and up to 6th order advection schemes. It includes multiple physics packages and dynamics options that can be combined to meet specific modeling needs. Our runs utilized the following packages: Morrison double-moment cloud microphysics scheme, Rapid radiative transfer model longwave radiation and Goddard shortwave radiation, Eta similarity surface layer, NOAH land surface model, MellorYamada-Janjic planetary boundary layer, and Kain-Fritsch cumulus parameterization (except in the $5 \mathrm{~km}$ grid where convection was explicitly resolved). Details about each of these schemes are described in Skamarock et al. (2008). Damping was employed at the model's top $(50 \mathrm{hPa})$ to prevent gravity wave reflection from the upper boundary. Finally, some of the modules were modified to be consistent with those used by the Polar Research Center's Polar WRF configuration (Bromwich et al., 2009; Hines and Bromwich, 2008).

We initialized WRF and updated its outer domain lateral boundary conditions every $6 \mathrm{~h}$ with data from the GFS. The GFS data were available on a $0.5^{\circ} \times 0.5^{\circ}$ latitude-longitude horizontal grid with 64 unequally-spaced sigma levels. Details about GFS are available at http://www.emc.ncep.noaa. gov/modelinfo/index.html. 


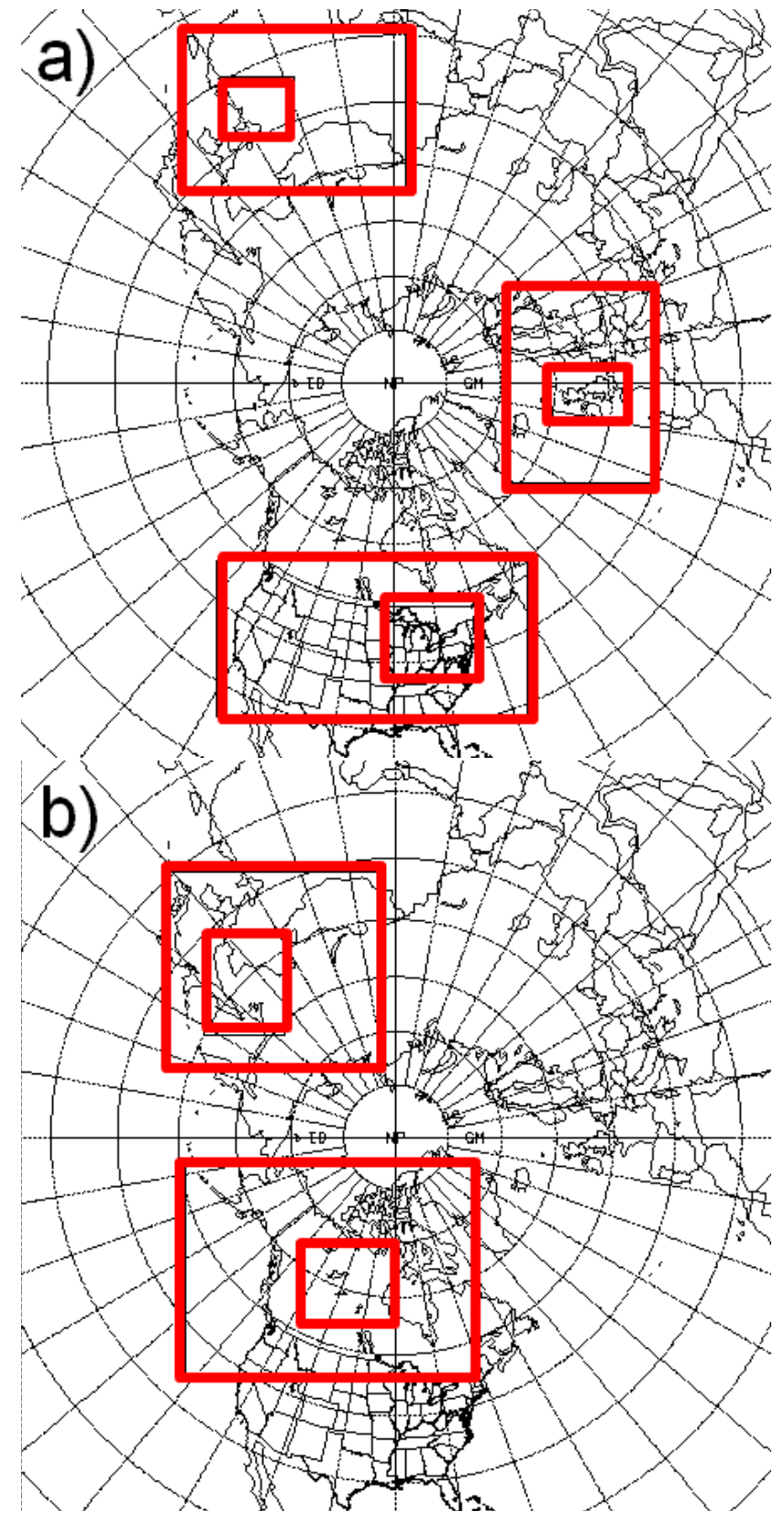

Fig. 1. Nested domains used for WRF runs during (a) Spring and (b) Summer 2008. Grid spacing for the three domains is $45 \mathrm{~km}$, $15 \mathrm{~km}$, and $5 \mathrm{~km}$.

\subsection{Trajectory model}

Trajectories were calculated using $u, v$, and $w$ wind components from the WRF hourly data at $45 \mathrm{~km}$ resolution. Additional details about our trajectory model are given in Fuelberg et al. (1996, 2000) and Martin et al. (2002). If a trajectory intersected the lower boundary, it was continued isobarically along the surface and possibly lofted later by vertical motion, a procedure similar to Stohl et al. (1995). Lim- itations of trajectories have been described by Fuelberg et al. (2000), Stohl (1998), Stohl et al. (1995), and others.

\subsection{FLEXPART model}

We ran the FLEXPART Lagrangian particle dispersion model (Stohl et al., 1998, 2005; Stohl and Thomson, 1999) to advect carbon monoxide (CO) from anthropogenic and biomass burning sources. $\mathrm{CO}$ is an excellent tracer since it has a mean lifetime of $\sim 2$ months (Jacob, 1999). The FLEXPART code was modified by Jerome Fast at the Pacific Northwest National Laboratory to utilize input from WRF model runs (Fig. 1), thereby permitting higher resolution than if GFS or ECMWF data had been used. The WRF nests at 15 and $5 \mathrm{~km}$ were positioned over areas of strong anthropogenic or biomass burning emissions to maximize their resolution. No removal processes (i.e., wet/dry deposition) were considered, and because FLEXPART is an "offline" model, no chemical feedback processes were included. FLEXPART ingested our WRF-derived wind data to calculate trajectories of tracer particles due to the mean wind, while WRF-derived sensible heat flux, friction velocity, and PBL height were ingested to diagnose the turbulent wind component.

Mass concentrations within FLEXPART were calculated on a user-defined grid, different from that employed in WRF. These calculations were made on a $10 \times 10 \mathrm{~km}$ grid $(180 \times 180$ grid point domain) with 28 vertical levels ranging from $0.05 \mathrm{~km}$ to $10 \mathrm{~km}$ above ground level (AGL) by summing the mass fraction of all particles within each grid cell and dividing by the volume of the cell. Detailed information about the FLEXPART Lagrangian particle dispersion model is given at http://transport.nilu.no/flexpart. The FLEXPART runs were initialized ten days before every ARCTAS flight.

\subsection{Emissions data}

Widespread fire activity occurred during the spring and summer phases of ARCTAS. Biomass burning CO emissions for our FLEXPART runs were from the Naval Research Laboratory's FLAMBE product which convolves GOES and MODIS satellite data to estimate fire locations and burn areas (Wang et al., 2006; Wang and Christopher, 2006, http:// www.nrlmry.navy.mil/flambe/). Specifically, FLAMBE uses the GOES-11 and GOES-12 infrared bands and the Wildfire Automated Biomass Burning Algorithm (WF_ABBA) to identify fires in the Western Hemisphere. Fire locations in other areas come from MODIS sensors on the Aqua and Terra satellites. We assumed that each remotely-detected fire covered a 180 hectare region, similar to Stohl et al. (2007). This assumption was based on a statistical analysis of fire detections and burned areas by Wotawa et al. (2006). Although FLAMBE data are available hourly, the MODIS instruments that are used to locate fires in Asia are in polar orbits, prohibiting continuous detection. Therefore, we only updated our fire data each day, assuming that any fire detected on 
a given day burned for $24 \mathrm{~h}$ (i.e., 00:00 to 23:59 UTC). Although an actual fire may not have burned the entire day, it still may have continued to emit CO. In fact, it is estimated that $84 \%$ of $\mathrm{CO}$ production occurs when a fire smolders (Levine 1991). Our assumption will over predict CO emission from fires that ignited late in the day and were subsequently detected. The proper injection heights for biomass burning emissions remain uncertain. For example, Labonne et al. (2007) concluded that most aerosols are injected within the boundary layer; however, Kahn et al. (2008) stated that at least $10 \%$ of wildfire smoke plumes reach the free troposphere. Our biomass burning emissions were released by filling each fire containing column with tracer particles from the surface to $1 \mathrm{~km}$ AGL. This altitude may be either too high or too low depending on local conditions.

FLAMBE utilized emission rates based on Seiler and Crutzen (1980), taking into account variations in fuel availability and biome dependent emission rates. Additional information about the methodology behind FLAMBE's emissions can be found at http://www.nrlmry.navy.mil/flambe/ papers/Emission\%20Rates\%20for\%20FLAMBE.pdf.

$\mathrm{CO}$ emissions from anthropogenic sources also were considered in the FLEXPART runs. We used a global $1^{\circ} \times 1^{\circ}$ gridded anthropogenic emissions dataset from the Center of Global and Regional Environmental Research (CGRER) which had been prepared in support of ARCTAS (for further information see http://www.cgrer.uiowa.edu/arctas/emission.html). We assumed no seasonal or diurnal variability in emissions and only included anthropogenic emissions that exceeded $1.15 \times 10^{4} \mathrm{~kg}(\mathrm{CO}) \mathrm{day}^{-1}$ to reduce computational requirements. The anthropogenic emissions were released through a $500 \mathrm{~m}$ deep column above the surface.

\subsection{Lightning data}

Lightning data were available from the Canadian Lightning Detection Network (CLDN) (Burrows and King, 2000; Burrows et al., 2002). The CLDN consists of 81 sensors that can detect and locate inter- and intra-cloud discharges (Orville et al., 2002). However, only a small percentage of cloud discharges are detected because the sensors are separated by $300-500 \mathrm{~km}$. An analysis of the CLDN by Vaisala, Inc. estimated that the flash detection efficiency is $85 \%-90 \%$ out to $200 \mathrm{~km}$ from the network's periphery, decreasing to $10 \%$ $30 \%$ at $300 \mathrm{~km}$ beyond the periphery.

No corrections were applied to the data to compensate for variations in detection efficiency and location accuracy across the study area, which produces an underestimate of flash counts. Weak positive flashes $(<15 \mathrm{kA})$ were deleted from the data set since they are thought to represent intracloud discharges. There currently is no way to continuously detect total lightning (cloud-to-ground plus intra-cloud) over Canada.

\section{The Spring Campaign (ARCTAS-A)}

\subsection{Mission averaged conditions}

We first present period-averaged flow patterns to describe composite transport during the spring phase of ARCTAS. Figure $2 \mathrm{a}$ contains time-averaged mean sea level pressure during ARCTAS-A, while the long term climatology for that period and the departure from climatology are given in Fig. $2 b$ and c, respectively.

Over the Pacific (Fig. 2), the central pressure of the subtropical anticyclone (the orange area) is $\sim 5 \mathrm{hPa}$ higher than normal, with the anticyclone extending farther north than usual. Thus, the "Aleutian Storm Track" (the magenta area) is displaced north of its typical position, causing mean sea level pressures over the Aleutians to be above normal, but below normal over the Beaufort Sea. Later sections will show that some individual North Pacific cyclones pass north of Alaska or over Central Alaska, instead of the more typical route over the Gulf of Alaska. Over Asia, the Siberian high is prominent; however, pressures over much of Northeastern Asia are below average, reflecting enhanced cyclonic activity near Lake Baikal. The polar anticyclone is located near its climatological position, and is somewhat stronger than normal. There is less than normal cyclonic activity off the East Coast of the US (e.g., Hatteras Lows) and the Canadian Maritimes (i.e., pressures there are greater than normal), but there is more cyclone activity over the Eastern North Atlantic, west of France and Spain. Thus, the western portion of the "Atlantic Storm Track" is weaker than usual, while the eastern part is more active.

The location of the arctic front varied from day to day during the ARCTAS-A period (not shown). Although generally located near $60^{\circ} \mathrm{N}$, it was farther south over Eurasia than North America. Due to the onset of spring, the front already had retreated from its southern most location during January.

Middle tropospheric conditions during ARCTAS-A are described using height contours at $500 \mathrm{hPa}$ (Fig. 3). Winds at this level blow approximately parallel to the contours, with greater geopotential heights to the right in the Northern Hemisphere. Heights are considerably higher than climatology over the North Pacific, consistent with the stronger than average warm core high pressure center at the surface (Fig. 2). Conversely, heights from Northern Siberia to Northern Alaska are below normal due to the enhanced surface cyclonic activity near Lake Baikal and the more northward tracks of the cyclones (Fig. 2). One should note that the height gradient from the Kamchatka Peninsula to Alaska is stronger (tighter) than usual, representing stronger than normal west to east flow in this region. Flow over the Northern Atlantic has a "Rex" type of blocking configuration, with ridging and greater than average heights near Greenland, but troughing and lower heights farther south where the gradient and westerly flow are weaker than climatology. 

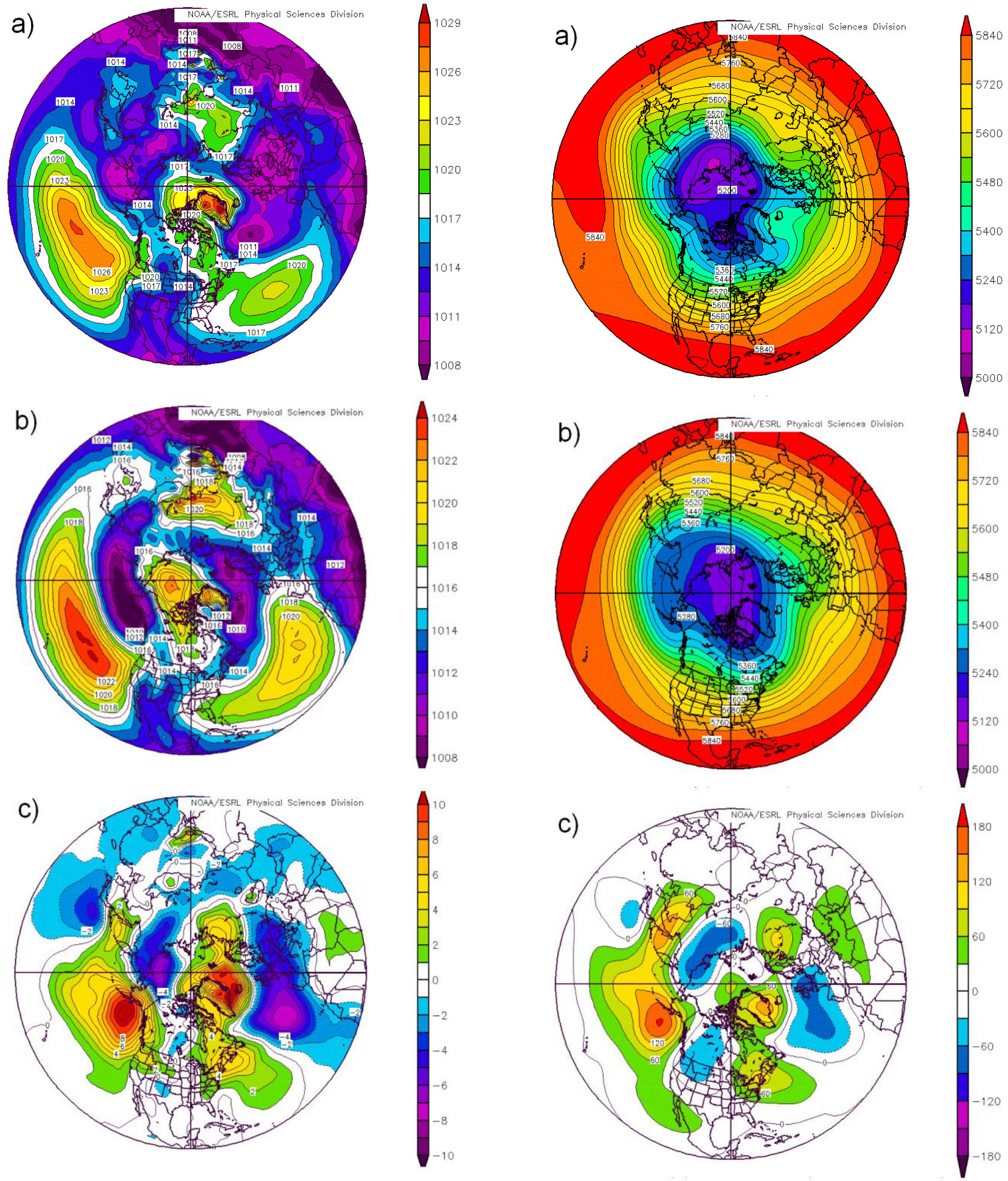

Fig. 2. Mean sea level pressure (hPa) for the period 30 March-22 April 2008. (a) Observed mean, (b) Climatological mean, (c) Departure from climatological mean. Analyses were prepared from the web site of the Climate Diagnostics Center (http://www.cdc.noaa. gov).

Fig. 3. $500 \mathrm{hPa}$ heights for the period 30 March-22 April 2008. (a) Observed mean, (b) Climatological mean, (c) Departure from climatological mean. Analyses were prepared from the web site of the Climate Diagnostics Center (http://www.cdc.noaa.gov). 
The North Atlantic Oscillation (NAO) is a prominent teleconnection pattern during all seasons (Barnston and Livezey, 1987). The NAO consists of a north-south dipole of anomalies, with one center over Greenland and the other, of opposite sign, spanning the middle latitudes of the North Atlantic Basin. The NAO is negative (-1.07) during ARCTAS-A (http://www.cpc.noaa.gov/products/precip/ CWlink/pna/month_nao_index.shtml), meaning that heights and pressures are above normal across the high latitudes of the North Atlantic, and below normal over the Central North Atlantic, Eastern US, and Western Europe (e.g., Fig. 3c). Negative NAO values have been associated with diminished pollution transport to the Arctic compared to the positive phase (Eckhardt et al., 2003; Duncan and Bey, 2004).

Wind vectors and isotachs $\left(\mathrm{m} \mathrm{s}^{-1}\right)$ at $300 \mathrm{hPa}$ denote the positions of the jet stream (Fig. 4). The major anomaly is over the North Pacific where the polar jet stream is north of its climatological position; westerly winds near the Bering Sea reach $\sim 15 \mathrm{~m} \mathrm{~s}^{-1}$ stronger than usual. The wind vectors farther south point in the opposite direction (from east to west), indicating weaker than normal westerly flow. Thus, transport from Asia toward North America occurs at higher latitudes than normal. Once again, this is consistent with the northward shift of the middle latitude cyclone track. The only other significant anomaly is over the North Atlantic where westerly flow is $\sim 15 \mathrm{~m} \mathrm{~s}^{-1}$ weaker than usual, although somewhat stronger than normal westerly flow is located west of France and Portugal.

\subsection{Example cases}

Although mean flow patterns are useful for revealing the overall meteorological conditions during ARCTAS-A, individual cyclones and anticyclones produce most of the transport. Therefore, it is informative to view sea level pressure patterns on several specific days based on our WRF model runs (Sect. 2.1). These and other meteorological parameters are available for both ARCTAS periods at http: //fuelberg.met.fsu.edu/research/arctas/traj/traj.html.

The descriptions that follow focus on middle latitude cyclones (lows) because they are regions of strong horizontal and vertical transport. Important climatological areas of cyclogenesis are located over Eastern Asia and the Western Pacific Ocean. These cyclones travel eastward toward North America and comprise the North Pacific storm track. The North Atlantic storm track consists of cyclones that form off the east coast of North America and near the Canadian Maritimes. These systems move eastward toward Europe. The cyclones are important mechanisms for transporting pollutants from the east coasts of both Asia and North America (Eckhardt et al., 2004; Cooper et al., 2002; Merrill and Moody, 1996; Stohl et al., 2002).

Ten day trajectories beginning near the surface Three specific pathways (or airstreams) often are identified in middle latitude cyclones - the warm and cold conveyor belts and
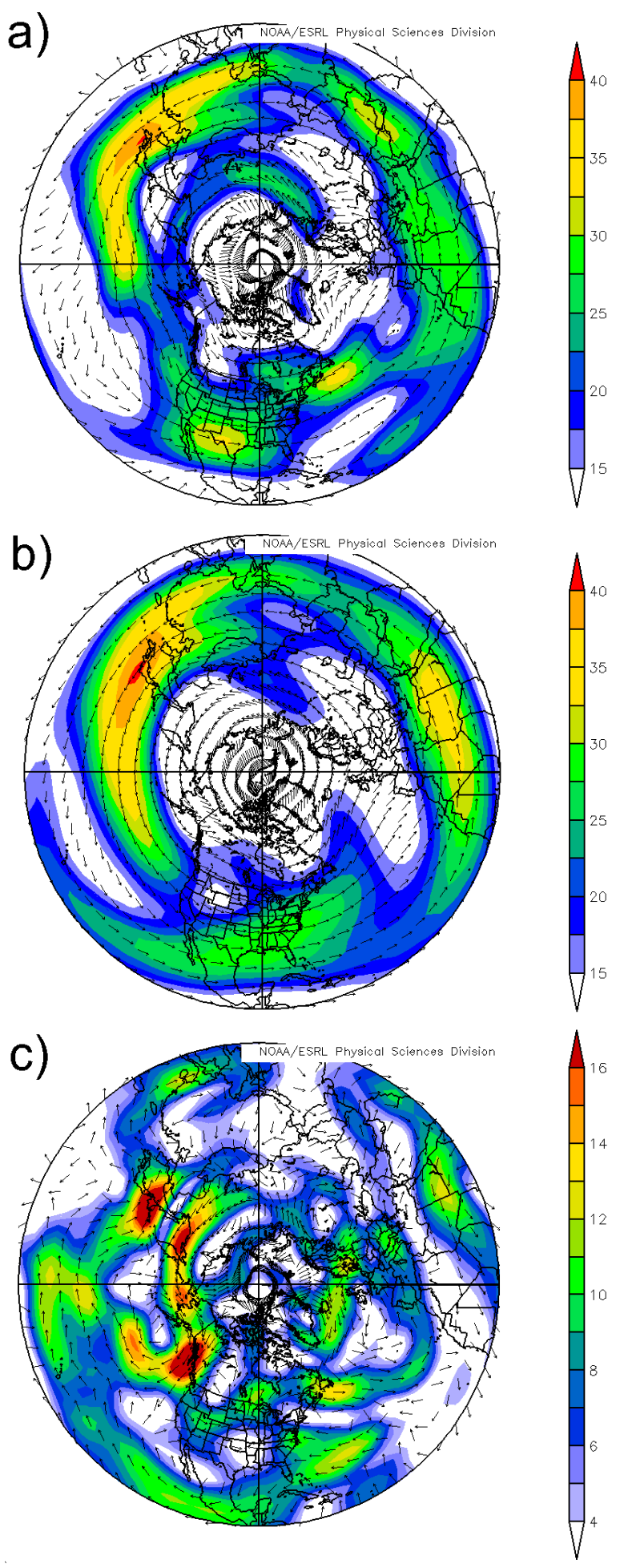

Fig. 4. Vector winds and isotachs $\left(\mathrm{m} \mathrm{s}^{-1}\right)$ at $300 \mathrm{hPa}$ for the period 30 March-22 April 2008. (a) Observed mean, (b) Climatological mean, (c) Departure from climatological mean. Analyses were prepared from the web site of the Climate Diagnostics Center (http://www.cdc.noaa.gov). 


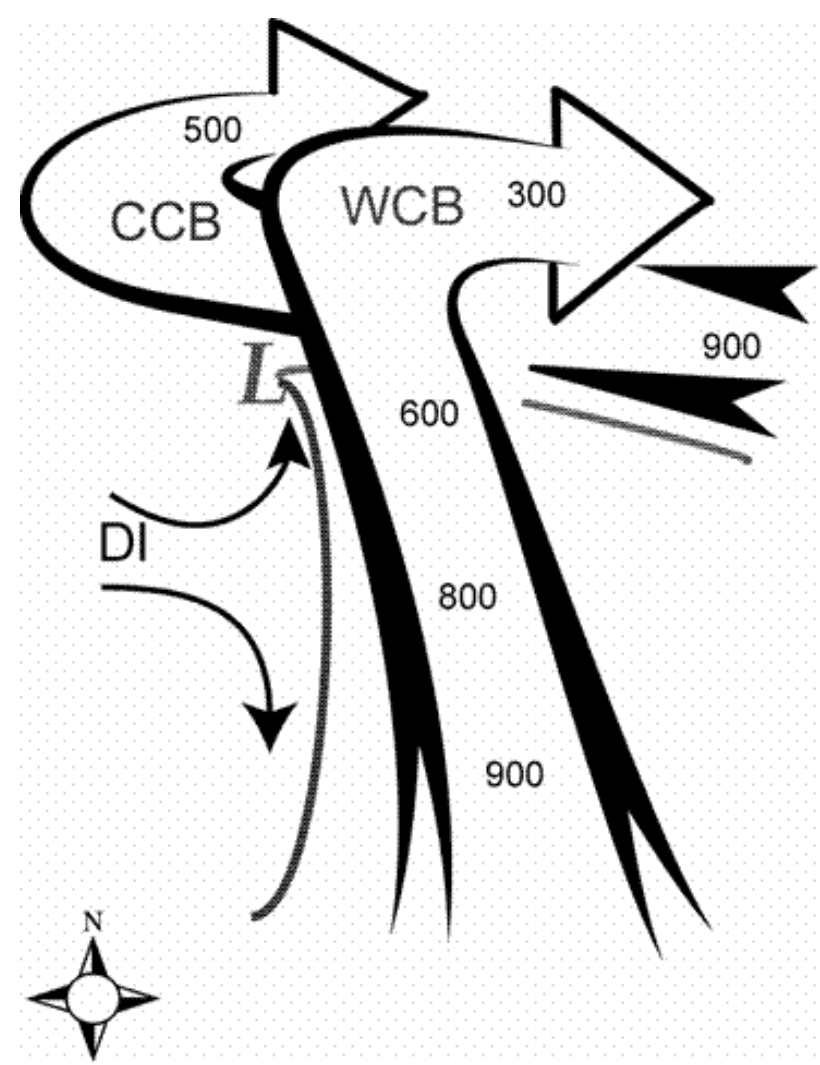

Fig. 5. Conceptual model of a middle latitude cyclone, with its surface position at $\mathrm{L}$ and its frontal systems depicted in the standard convention. The broad arrow labeled WCB represents the warm conveyor belt. The arrow CCB is the cold conveyor belt. The dry intrusion is labeled DI. The numbers denote typical heights $(\mathrm{hPa})$ of the CCB and WCB (Adapted from Djuric, 1994).

the dry intrusion (Fig. 5) (Bader et al., 1995; Browning and Monk, 1982; Browning and Roberts, 1994; Carlson, 1998). The warm conveyor belt (WCB) is the major transporter of pollutants (Eckhardt et al., 2004; Stohl et al., 2002). It begins near the surface in advance of the cyclone's cold front (its warm sector). If the cyclone is located sufficiently offshore, relatively clean maritime air will be transported aloft by the WCB. However, if the low is closer to land, biomass burning by-products or other surface based pollutants from heavily industrialized regions such as Eastern Asia and Eastern North America can be ingested. The pollution laden air ascends in the WCB to the middle and upper troposphere where it begins to move eastward and gradually becomes part of the background westerly flow. The cold conveyor belt is located completely within the cold sector of the cyclone (Fig. 5). Except for Cooper et al. (2001), cold conveyor belts have received relatively little attention

The dry air intrusion (DI) originates in the upper troposphere and lower stratosphere (Fig. 5). It typically is located northwest of the cyclone and descends into the middle to lower troposphere. Tropopause folds related to transverse circulations along the jet stream often occur in this region behind the cold front (Danielsen 1968). Thus, the DI can transport upper tropospheric or stratospheric air into the middle or lower troposphere. Stohl (2006) investigated the role of stratospheric/tropospheric exchange in the Central Arctic. During the summer he found only a negligible probability of stratospheric air reaching the polar surface within 20 days. During winter, when deep stratospheric/tropospheric exchange is more vigorous (Sprenger and Wernli, 2003; James et al., 2003), the probability still was only $\sim 1 \%$ over a 10 day period. Based on these results, we will not pursue stratospheric/tropospheric exchange. Finally, some authors have described a cold, dry post cold frontal airstream in the middle to lower troposphere beneath the DI and behind the surface cold front (Cooper et al., 2001).

Middle latitude cyclones were important transport systems during ARCTAS-A, and 3 April 2008 is a prime example of intense cyclones traversing the North Pacific storm track during the first third of the period (Fig. 6a). The cyclone over Siberia (the red area) had formed near Lake Baikal several days earlier and moved relatively little before dissipating over the northeast coast of Siberia two days later (not shown). The second major cyclone, centered over the Bering Sea, formed near Japan and was moving northeastward toward Alaska. It then turned sharply northward and dissipated over Alaska's North Slope. Finally, the weak cyclone north of Alaska also formed near Japan, reached maximum intensity over the North Pacific, and began to dissipate as it moved over the Bering Strait. Both the Japanese and Lake Baikal areas are climatologically favored regions for cyclone formation, and the first week of ARCTAS-A exhibited a rapid succession of these storms. However, cyclones passing near the Bering Strait are rather uncommon; the more typical route is over the Gulf of Alaska. The North Atlantic experiences less cyclonic activity than the Pacific during the early phase of ARCTAS-A (Fig. 6a). Only two major systems form near the Canadian Maritimes. The second of these cyclones is centered over the Maritimes on 3 April (Fig. 6a), but soon dissipates near the southern tip of Greenland.

Meteorological conditions during the middle third of ARCTAS-A are considerably different from earlier (Fig. 6b). There is relatively little cyclogenesis near Lake Baikal and Japan; those storms that do form are weaker than previously; and they follow a more easterly path before dissipating over Northern Alaska. The analysis for 9 April (Fig. 6b) shows that the Pacific subtropical high pressure area (the blue region) has expanded and moved north of its earlier location (e.g., Fig. 6a). On the other side of the globe, however, enhanced cyclone activity is occurring over the North Atlantic. Major cyclones form east of Greenland, near Scandinavia, and west of Portugal, with one system passing between Greenland and Baffin Island.

The last week of ARCTAS-A exhibits renewed strong cyclone activity over the North Pacific (Fig. 6c). The systems 

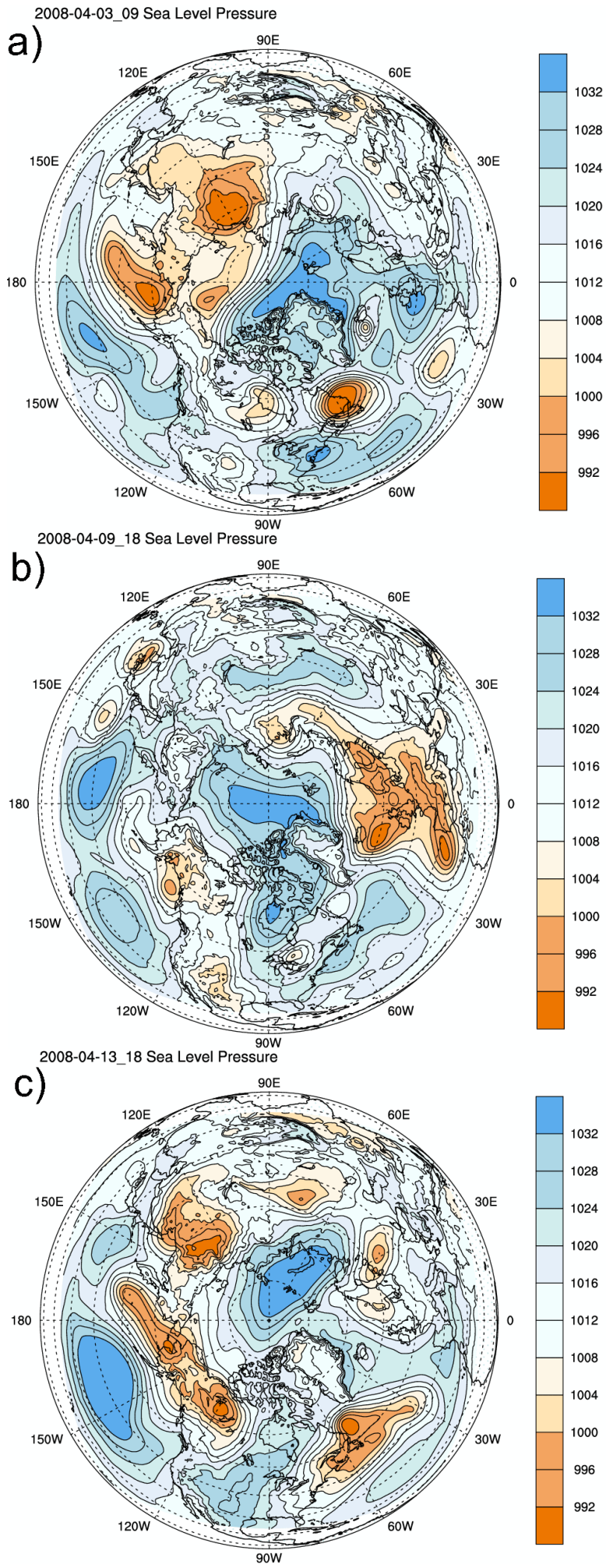

Fig. 6. Surface pressure analyses at $4 \mathrm{hPa}$ intervals from the FSU WRF runs. (a) 3 April 2008, (b) 9 April 2008, (c) 13 April 2008. Data available at http://fuelberg.met.fsu.edu/research/arctas/ traj/traj.html.
Table 1. Percentage of 10 day forward trajectories reaching $70^{\circ} \mathrm{N}$ after being released at three levels at 0000 UTC each day on a $5^{\circ}$ latitude by $10^{\circ}$ longitude grid encompassing most of the Northern Hemisphere (Fig. 1).

\begin{tabular}{lll}
\hline Release Altitude & ARCTAS-A & CARB and ARCTAS-B \\
\hline $300 \mathrm{hPa}$ & $22 \%$ & $20 \%$ \\
$500 \mathrm{hPa}$ & $18 \%$ & $19 \%$ \\
Surface & $19 \%$ & $15 \%$ \\
Combined 3 levels & $20 \%$ & $18 \%$ \\
\hline
\end{tabular}

Table 2. Altitudes at which 10 day forward trajectories reach $70^{\circ} \mathrm{N}$. The trajectories were released at the surface, $500 \mathrm{hPa}$, and $300 \mathrm{hPa}$ at 0000 UTC each day on a $5^{\circ}$ latitude by $10^{\circ}$ longitude grid encompassing most of the Northern Hemisphere (Fig. 1).

\begin{tabular}{lll}
\hline Pressure Layer & ARCTAS-A & CARB and ARCTAS-B \\
\hline$<400 \mathrm{hPa}$ & 42.7 & 46.0 \\
$400-<700 \mathrm{hPa}$ & 36.4 & 36.2 \\
$>700 \mathrm{hPa}$ & 20.9 & 17.8 \\
\hline
\end{tabular}

again form near Lake Baikal and Japan and then move eastward, but following a more southerly track than during the first week. Thus, they come onshore over Central and Southern Alaska and British Columbia. The North Atlantic continues having a series of major cyclones, with some passing south of Greenland and others impacting Western Europe. The North Pole is dominated by strong high pressure.

\subsection{Transport to the Arctic}

We investigated the sources and paths taken by air entering the Arctic (defined as north of $70^{\circ} \mathrm{N}$, as in Stohl, 2006, and others) by using 10 day forward trajectories calculated using FSU's hourly WRF output. This ARCTAS overview does not explore transport in the detail provided by Klonecki (2003) for the year 2000; however, we will present more detailed results in a separate paper. As the first step, we released a trajectory each day at 00:00 UTC on a $5^{\circ}$ latitude by $10^{\circ}$ longitude grid (324 trajectories) encompassing most of the Northern Hemisphere (Fig. 1). The releases were made at pressure altitudes of $300 \mathrm{hPa}, 500 \mathrm{hPa}$, and near the surface (but not exceeding $1000 \mathrm{hPa}$ ). Those trajectories that reached $70^{\circ} \mathrm{N}$ were noted. Then, their pathways were traced on a $1^{\circ} \times 1^{\circ}$ grid, and the altitudes at which they reached $70^{\circ} \mathrm{N}$ were documented. Results for the composite ARCTAS-A period are given in Tables 1 and 2 and Figs. 7-9. The overall finding is that $\sim 20 \%$ of the daily trajectory releases reach $70^{\circ} \mathrm{N}$ within 10 days (Table 1). The altitude at which the trajectories were released (surface, 500 , or $300 \mathrm{hPa}$ ) does not play a major role in determining whether trajectories will reach the Arctic. Instead, the deciding factor is the specific path 

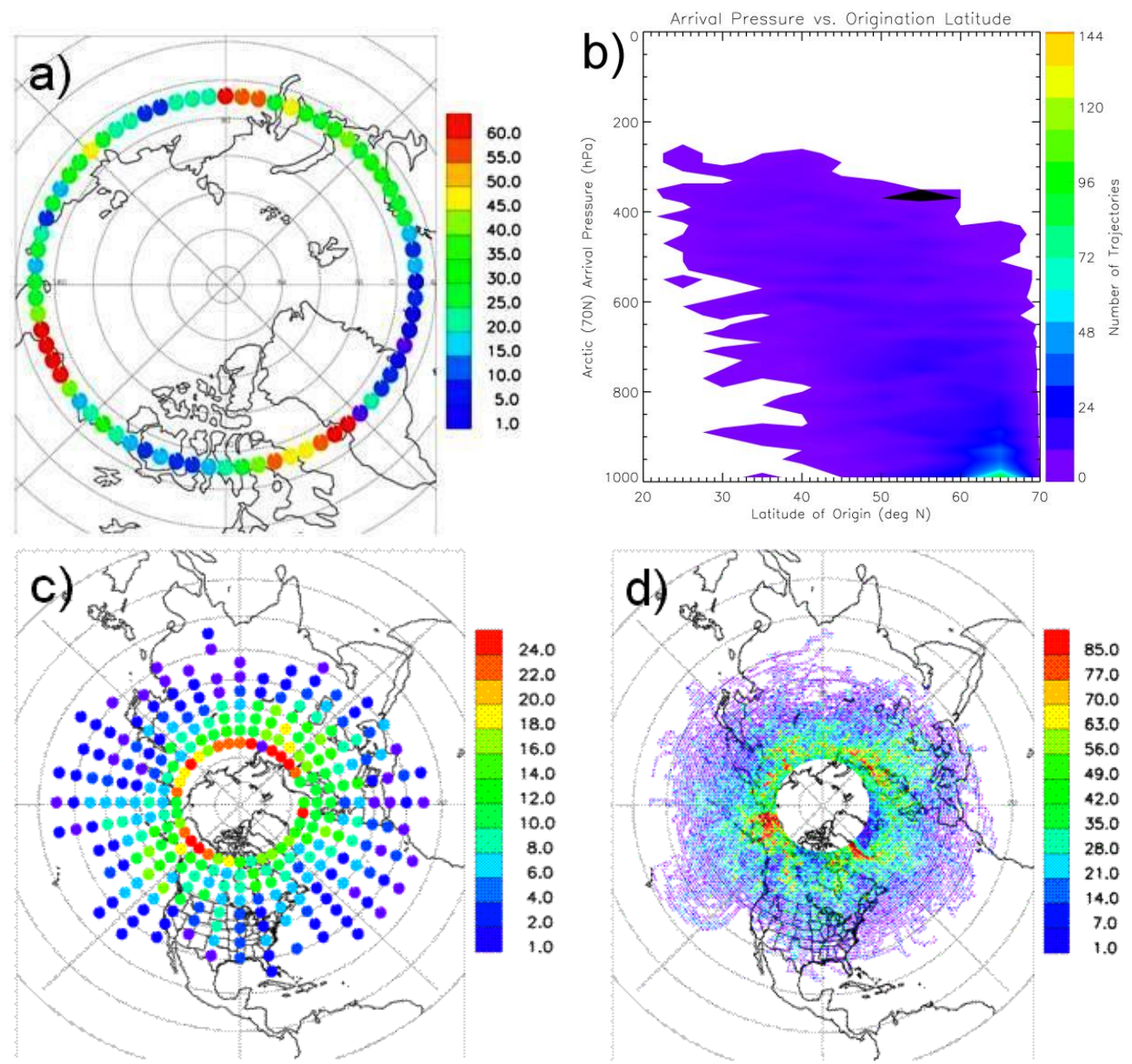

Fig. 7. (a) The number of 10 day forward trajectories reaching $70^{\circ} \mathrm{N}$. Values are given at intervals of $5^{\circ}$ longitude. The trajectories were released near the surface at 00:00 UTC each day during ARCTAS-A on a $5^{\circ}$ latitude by $10^{\circ}$ longitude grid (11340 total grid points) encompassing most of the Northern Hemisphere (Fig. 1). (b) Pressure altitudes of those trajectories arriving at $70^{\circ} \mathrm{N}$ as a function of their latitude of release. (c) Initial locations and numbers of the trajectories reaching $70^{\circ} \mathrm{N}$ during the 10 day period. (d) The number of trajectories passing over $1^{\circ} \times 1^{\circ}$ grid boxes during their paths to $70^{\circ} \mathrm{N}$.

and altitude taken by a parcel and whether the winds encountered along its path are sufficiently strong to transport it to the Arctic within the 10 day computational period.

Ten day trajectories beginning near the surface reach $70^{\circ} \mathrm{N}$ in three major regions - near Baffin Island and Western Greenland, Northern Alaska, and Eastern Europe through Central Russia (Fig. 7a). Although the trajectories originate near the surface, they undergo considerable vertical displacement during the 10 day period and arrive at $70^{\circ} \mathrm{N}$ at a wide range of altitudes (Fig. 7b). $42 \%$ of the trajectories reach $70^{\circ} \mathrm{N}$ at pressure altitudes less than $700 \mathrm{hPa}$, while $36.4 \%$ arrive in the middle troposphere, and $42.7 \%$ arrive at pressures less than $400 \mathrm{hPa}$ (Table 2). Trajectories beginning in the low latitudes generally reach $70^{\circ} \mathrm{N}$ at high altitudes, while those originating in the middle and high latitudes arrive throughout the troposphere. This distribution occurs because trajectories beginning at low latitudes must travel long distances to reach $70^{\circ} \mathrm{N}$ within the 10 day computational period. This can only occur if they encounter relatively strong winds which tend to occur in the middle latitude upper troposphere. Furthermore, air parcels follow surfaces of constant potential temperature as long as conditions are adiabatic. Since these surfaces slope upward from the tropics toward the pole, parcels will tend to rise as they approach the pole (e.g., Raatz, 1991; Klonecki et al., 2003). Conversely, parcels reaching $70^{\circ} \mathrm{N}$ from the middle and high latitudes do not have to travel as rapidly as those beginning farther south. Thus, they can experience both upward and downward displacements and still arrive within 10 days. Middle latitude cyclones are associated with ascending air, clouds, and precipitation, whereas high pressure areas located between the cyclones are characterized by subsidence and generally little cloud cover. Thus, parcels do not simply ascend along isentropic surfaces as they approach the Arctic, but can undergo diabatic ascent or descent during their 10 day transits. Even parcels that begin near the surface at high latitudes can experience large ascent (Fig. 7b). 

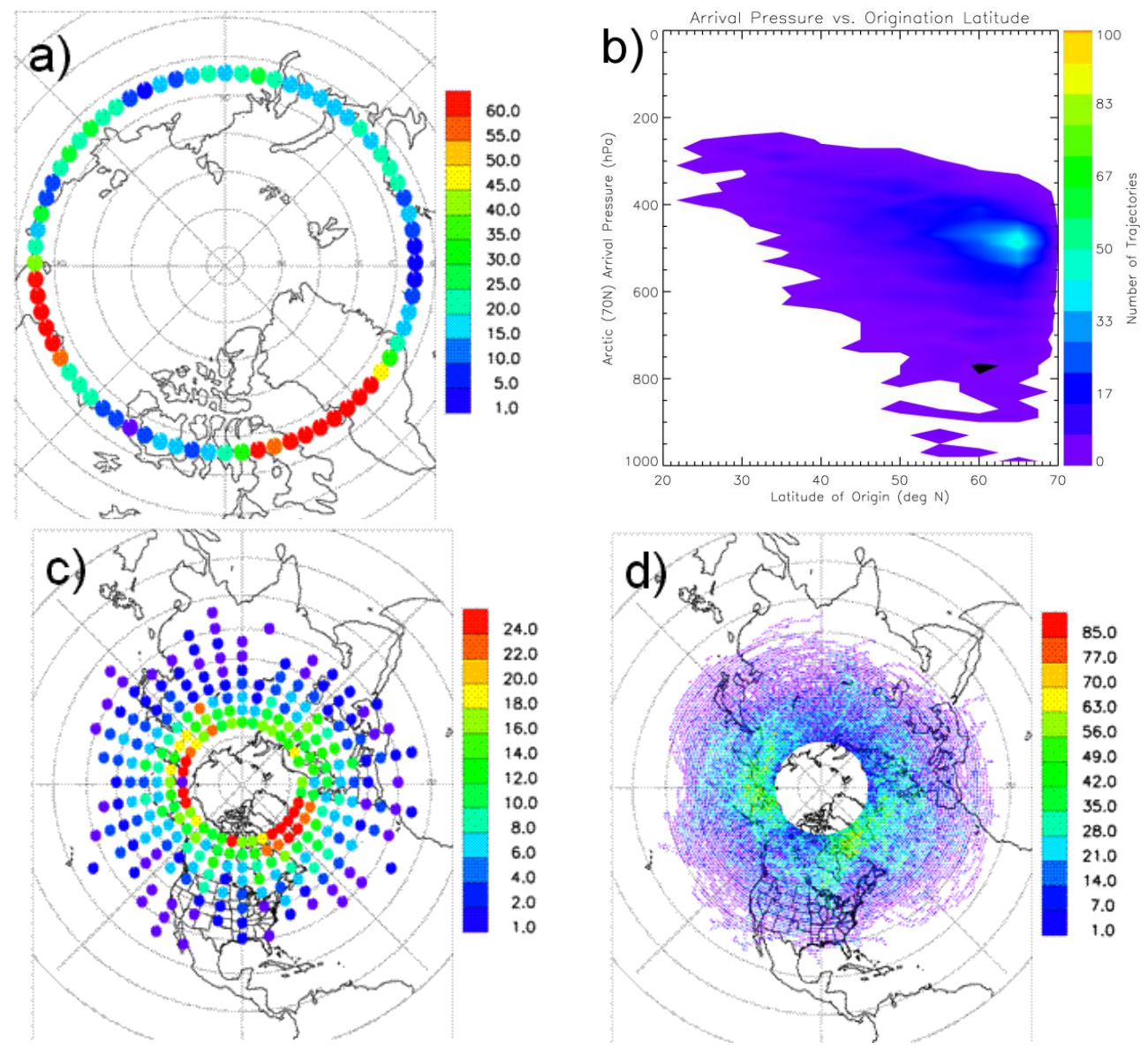

Fig. 8. As in Fig. 7, but for trajectories released at $500 \mathrm{hPa}$.

Trajectories that begin near the surface and arrive at $70^{\circ} \mathrm{N}$ originate from a wide range of locations (Fig. 7c), with some of the 10 day initiation points being as far south as $25^{\circ} \mathrm{N}$. The two most common initiation regions are the Eastern Pacific Ocean as well as Europe and Western Asia. Finally, trajectories entering the Arctic region follow a large variety of paths (Fig. 7d). In fact, virtually no region north of $30^{\circ} \mathrm{N}$ is immune from air aloft reaching the Arctic within 10 days. The two most common paths are over Alaska and the west coast of Greenland whose inland high elevations tend to block the flow; however, Northern Eurasia also exhibits scattered areas of frequent paths.

Flow patterns at $500 \mathrm{hPa}(\sim 5.5 \mathrm{~km})$ are more sinusoidal than those near the surface where closed pressure systems dominate (Figs. 2-3). The result is very apparent in the trajectories released at $500 \mathrm{hPa}$ (Fig. 8). The two major entrance regions to the Arctic (Fig. 8a) are Alaska and the Bering Sea, and near Baffin Island and Greenland. Both are near areas of major surface cyclone activity and associated upper level troughs (Figs. 3a, 6). Winds east of a trough usually have a strong component toward the north. It is interesting that Central Russia is a much less important entrance region than it was for releases near the surface. The distribution of entrance altitudes at $70^{\circ} \mathrm{N}$ (Fig. 8b) again is very broad, similar to that seen near the surface (Fig. 7b). However, few air parcels released at $500 \mathrm{hPa}$ reach $70^{\circ} \mathrm{N}$ at altitudes below $\sim 750 \mathrm{hPa}$. Initiation locations for air reaching the Arctic (Fig. 8c) generally are farther north than for releases near the surface, reflecting the more zonal flow. The two most common pathways to the Arctic are over Northeastern Siberia and the North Pacific as well as the North Atlantic (Fig. 8d). Conversely, there is relatively little transport over Northern Canada and Eurasia.

Finally, trajectory characteristics at $300 \mathrm{hPa}$ (Fig. 9) are similar to those at $500 \mathrm{hPa}$ (Fig. 8). The prominent entrance regions are Northern Alaska plus Greenland and Baffin Island (Fig. 9a). The trajectories released at $300 \mathrm{hPa}$ and arriving at $70^{\circ} \mathrm{N}$ do so over a relatively narrow range of altitudes, with the great majority arriving between $250-450 \mathrm{hPa}$ (Fig. 9b). Most trajectories reaching the Arctic originate north of $50^{\circ} \mathrm{N}$ (Fig. 9c), consistent with the relative lack of meridional flow in the upper troposphere and the comparatively light winds at these high latitudes. The major transport pathways to the Arctic (Fig. 9d) are similar to those 

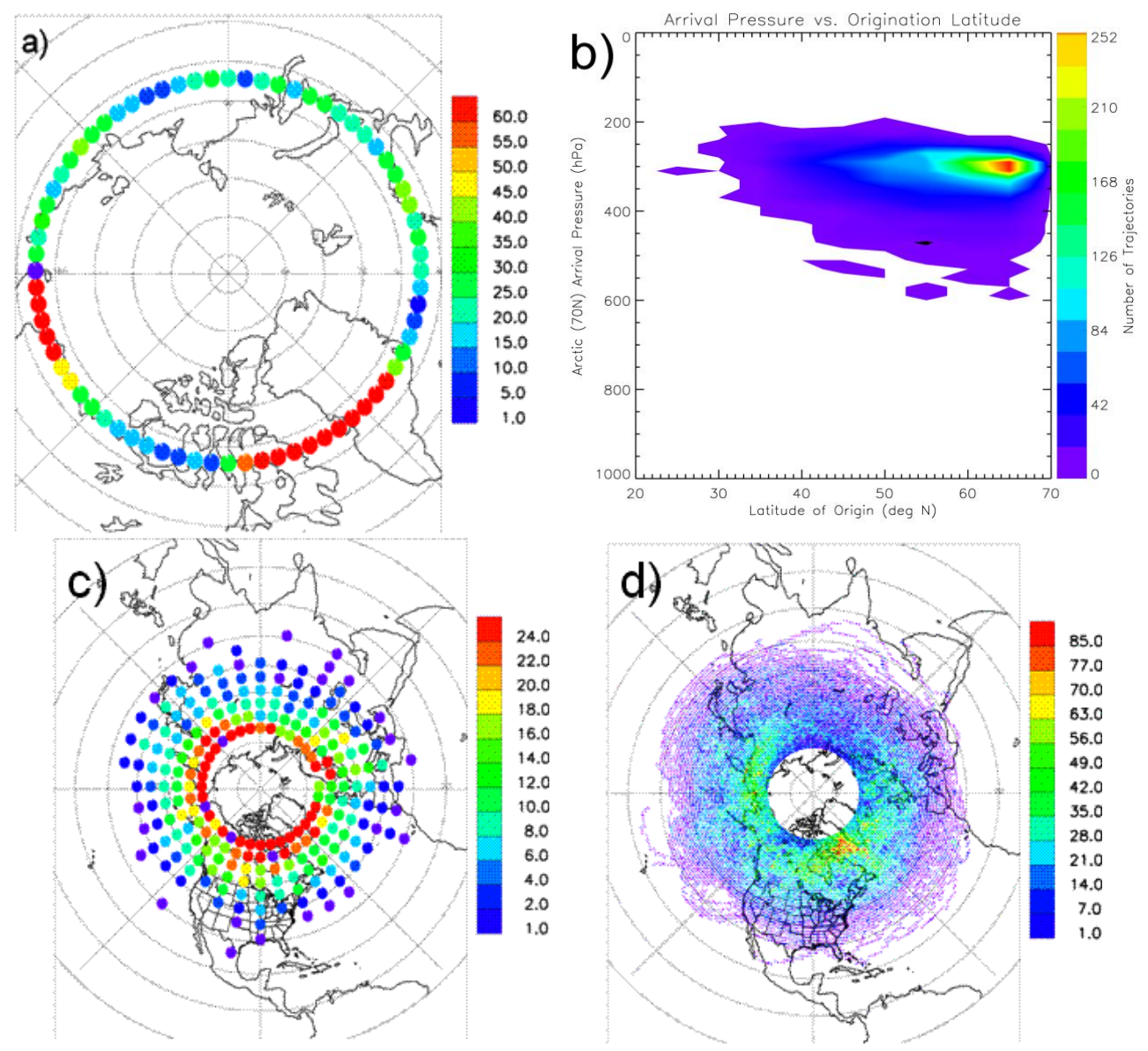

Fig. 9. As in Fig. 7, but for trajectories released at $300 \mathrm{hPa}$.

at $500 \mathrm{hPa}$, i.e., over the North Pacific and North Atlantic Oceans.

To summarize, Eastern Siberia and Alaska, Baffin Island/Western Greenland, and Eastern Europe through Central Russia are the major entrance regions to the Arctic for air departing near the surface during ARCTAS-A. Most parcels released at 500 and $300 \mathrm{hPa}$ enter the Arctic in only the first two of these areas. Several previous studies of Arctic transport have utilized tracers that were tagged with their region of origin (e.g., Stohl, 2006; Klonecki et al., 2003). Their results emphasized winter and spring transport from Eurasia, with only weak transport from North America. However, the current results, based on forward trajectories (Figs. 7c-9c), reveal a more complex scenario that depends on the altitude of the trajectory release. Specifically, trajectories released at altitudes of 700 and $300 \mathrm{hPa}$ (Figs. 8c and 9c) suggest that North America was an important origination for air reaching the Arctic during ARCTAS-A.

Several factors must be considered when comparing current results with those of previous studies. First, ARCTAS-A was conducted during a very limited period during the early Arctic spring, a time of major seasonal transition in atmo- spheric flow patterns. Conversely, most other studies considered longer periods that sometimes included both winter and spring. The second and probably most important point is the relation between Arctic transport and the NAO. The NAO was decreasing rapidly prior to and during the ARCTAS-A period, being 0.89 during January, 0.08 in March, -1.07 in April (the ARCTAS period), and -1.73 in May. Based on FLEXPART dispersion studies over a $15 \mathrm{yr}$ period, Eckhardt et al. (2003) found that European tracer largely was confined to south of $60^{\circ} \mathrm{N}$ during negative NAO, but reached $70^{\circ} \mathrm{N}$ for positive NAO. Similarly, after 8-10 days, most of the European tracer was south (north) of the Arctic Circle during negative (positive) NAO. For North American tracers, Eckhardt et al. (2003) noted that transport was slower and directed more toward lower latitudes during periods of negative NAO. Thus, comparisons between studies must include a discussion of the NAOs that were occurring, a subject more suitable for detailed studies, not this overview paper.

Arctic haze is a maximum during the winter and early spring and traditionally has been attributed to anthropogenic pollution in extreme Northern Eurasia, north of the Arctic front (Barrie et al, 1994; Barrie and Hoff, 1985). However, 


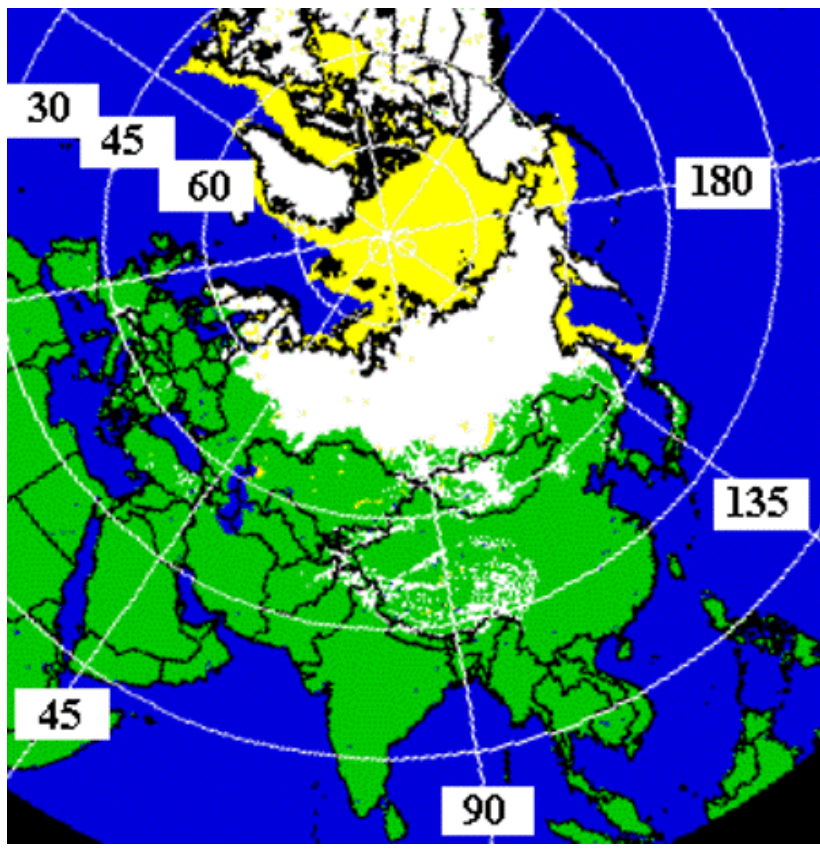

Fig. 10. Snow cover on 1 April 2008. Data are from the NOAA National Climatic Data Center at http://www.ncdc.noaa. gov/snow-and-ice/. Snow is denoted by white, and ice by yellow.

a recent study of fires in Eastern Europe during Spring 2006 (Stohl et al., 2007) concluded that biomass burning has been underestimated as a source of Arctic aerosols and trace gases. Widespread fires over Russia during ARCTAS-A (Jacob et al., 2009; Warneke et al., 2009) were an important source of arctic pollution. The fires during Spring 2008 started unusually early and consisted of agricultural burning in Northern Kazakhstan and Southern Russia, likely caused by farmers clearing their fields for spring planting, and boreal forest fires between Lake Baikal and the Amur River in Southern Siberia (Warneke et al. 2009). The agricultural burning typically lasts for a few weeks, while the forest fires continue through the summer (Stohl et al., 2007; Generoso et al., 2009; Warneke et al. 2009).

The extent of snow cover on 1 April 2008, near the beginning of ARCTAS-A, is shown in Fig. 10. The southern boundary of the snow generally is several hundred kilometers north of the border between China and Russia/Mongolia, which is farther north than observed since data became available in 1997. Warneke et al. (2009) proposed that the early onset of fires during April 2008 was attributable to the small snow amount in Siberia and Russia. The relatively small extent of snow cover can be partially attributed to the warmer than normal surface temperatures over most of Russia and China (Fig. 11). In fact, departures over Southeastern Russia reach a surprising $6-8{ }^{\circ} \mathrm{C}$ warmer than the long term average for March and April. Stohl (2006) noted that an earlier fire season in Siberia leads to enhanced low level transport to the

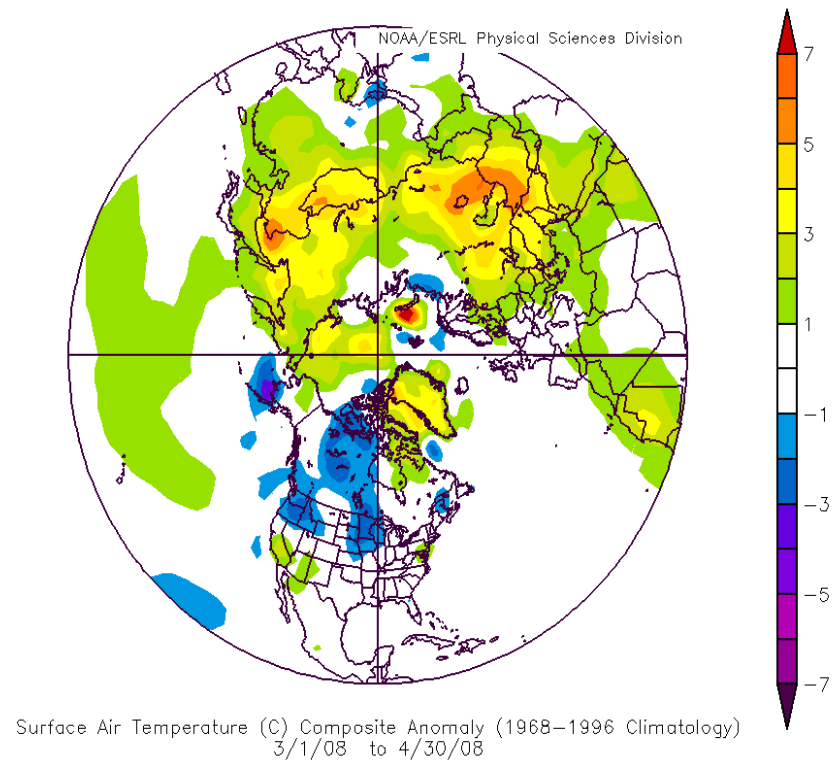

Fig. 11. Departure of the surface temperature $\left({ }^{\circ} \mathrm{C}\right)$ for the period 1 March-30 April 2008 from the climatological mean between 19681996. The analysis was prepared from the web site of the Climate Diagnostics Center (http://www.cdc.noaa.gov).

Arctic based on isentropic considerations. The early onset of fires in Asia is a significant feature of ARCTAS-A that must be considered when interpreting the chemical data.

The FLEXPART Lagrangian particle dispersion model (Stohl et al., 2005) is an excellent tool for determining the sources and pathways of both anthropogenic and biomass burning pollution that entered the Arctic during ARCTASA (Fig. 12). Animations of FLEXPART runs for all ARCTAS flight days are available at http://fuelberg.met.fsu.edu/ research/arctas/traj/traj.html. The Norsk Institutt for Luftforskning (NILU) website for ARCTAS also contains extensive products derived from FLEXPART (http://transport. nilu.no/flexpart-projects?cmp=ARCTAS). Figure 12a shows two areas of enhanced anthropogenic pollution at $9 \mathrm{~km}$ on 16 April. One plume began over Northwestern Russia and traveled northward to reach the North Pole; the second plume also began over Northwestern Russia but traveled over Northern China before turning north to reach $\sim 73^{\circ} \mathrm{N}$. Anthropogenic pollution from the US that reaches the Arctic at $5 \mathrm{~km}$ altitude is shown in Fig. 12b. The plume first became evident at $5 \mathrm{~km}$ near Lake Michigan on 1 April, passed over Newfoundland on 3 April, and later moved northward and deformed into a series of spiral bands over Baffin Island and Southern Greenland on 7 April. An area of anthropogenic pollution also is seen over Northern Europe at this time.

Southern Russia was a region of extensive biomass burning, and a plume that originated there reached Alaska on 9 April (Fig. 12c). This biomass burning plume and some others during ARCTAS-A did not extend north of $\sim 70^{\circ} \mathrm{N}$, but instead headed back south into the westerlies. Figure $12 \mathrm{~d}$ 

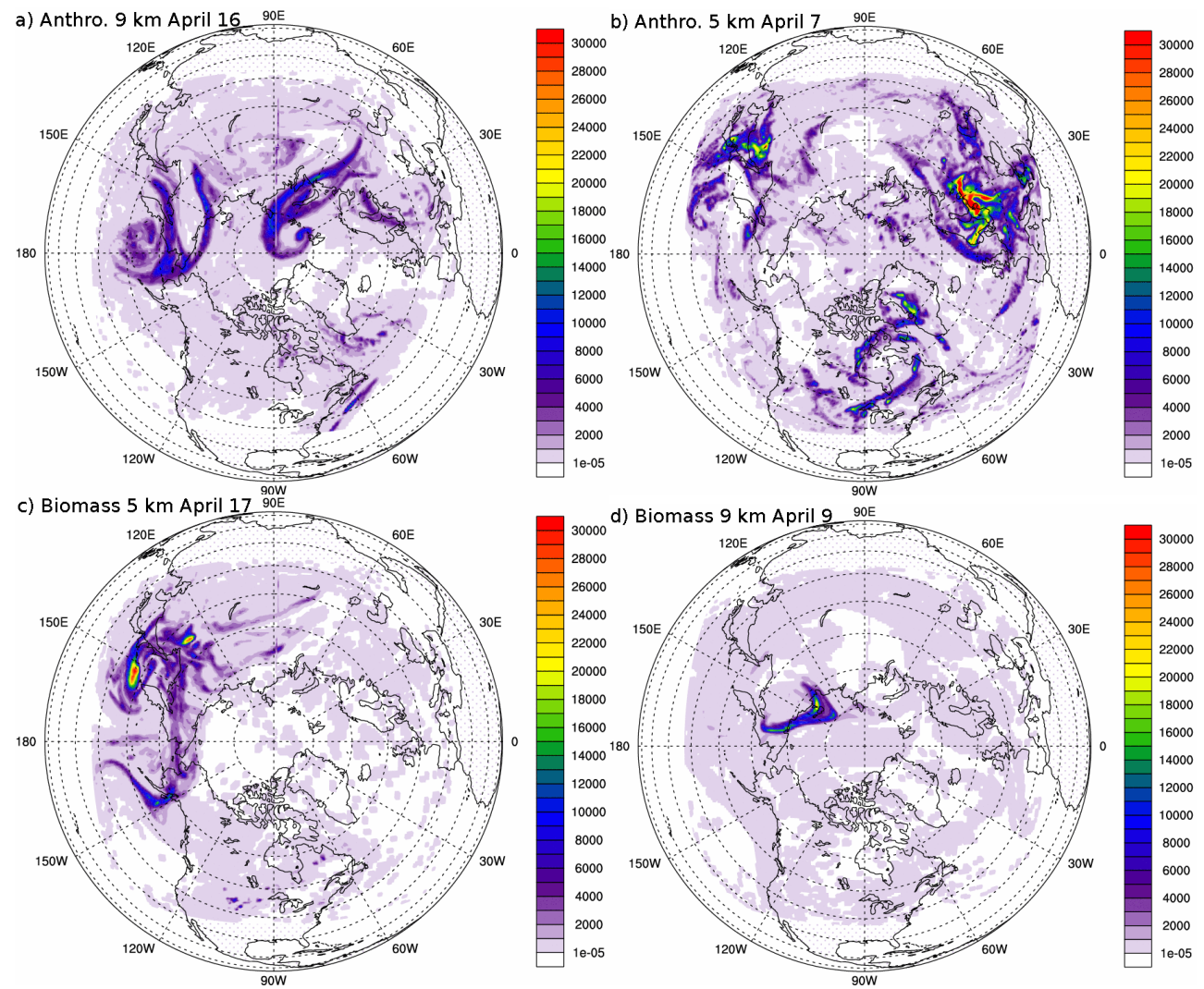

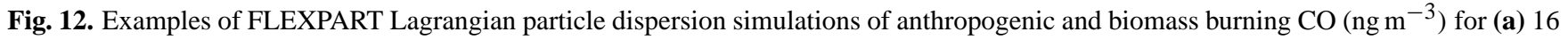
April 2008 at $9 \mathrm{~km}$, (b) 7 April 2008 at $5 \mathrm{~km}$, (c) 17 April 2008 at $5 \mathrm{~km}$, and (d) 9 April 2008 at $9 \mathrm{~km}$. Simulations for all flights are available at http://fuelberg.met.fsu.edu/research/arctas/traj/traj.html.

illustrates a biomass burning plume that began near $50^{\circ} \mathrm{N}$, $130^{\circ} \mathrm{E}$, was quickly lofted to $9 \mathrm{~km}$, and then reached $\sim 83^{\circ} \mathrm{N}$. It is clear that biomass burning by-products from Asia were transported to the high Arctic during the April campaign.

The three ARCTAS aircraft sampled Arctic air that had many origins and followed many different pathways. We calculated backward and forward trajectories along each flight of each aircraft. Figure 13 depicts several interesting pathways of air sampled by the aircraft. Many parcels originate over Asia 10 days earlier. Some follow relatively straight eastward paths to the Arctic (e.g., Fig. 13a), while others travel more undulating routes due to the influence of middle latitude cyclones and anticyclones (e.g., Fig. 13b). Some of the paths are almost circumpolar during the 10 day period (Fig. 13c). Conversely, stagnant pressure patterns can cause air to follow tight, nearly circular paths, repeatedly passing over the same surface (Fig. 13d). Air sampled near Greenland sometimes passes over the US Midwest, even originating over the Gulf of Mexico as part of a warm conveyor belt (Fig. 13e). Finally, some low level flights (e.g., Fig. 13f) sampled air that was influenced by slowly moving but intense middle latitude cyclones.

\section{The Summer Campaign (CARB and ARCTAS-B)}

\subsection{Mission averaged conditions}

The seasonal variability of Arctic transport has been stressed by Stohl (2006), Klonecki et al. (2003), and others. Meteorological systems during summer generally are less intense than during winter; wind speeds are reduced causing slower transport; there is greater vertical mixing due to fewer and less intense surface based temperature inversions; and there is more deep convection that produces rapid vertical transport. The ARCTAS-B summer campaign allowed comparisons with results from spring. Flights for the CARB mission occurred between 18-24 June 2008, followed by ARCTAS-B flights over the Arctic that continued through mid July.

As expected, meteorological conditions over the Northern Hemisphere changed considerably since spring. However, sea level pressures over most of the region during the summer period are within $4 \mathrm{hPa}$ of climatology (Fig. 14c); the only exception is Greenland whose mean pressure is $\sim 10 \mathrm{hPa}$ greater than normal. The Pacific and Atlantic Oceans continue to be dominated by semi-permanent subtropical high pressure (orange areas in Fig. 14a). Clockwise flow around 

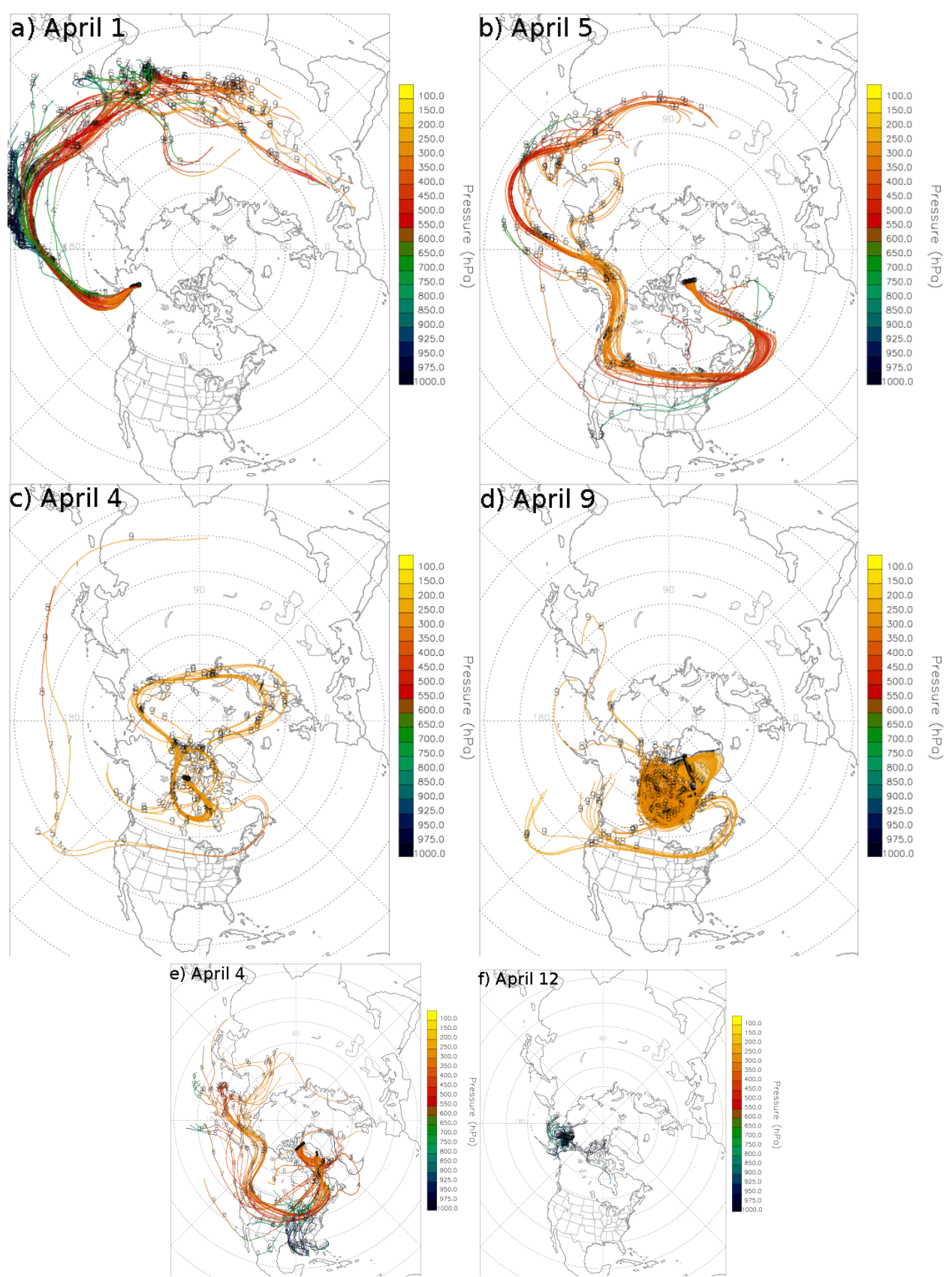

Fig. 13. 10 day backward trajectories showing examples of air sampled by the DC- 8 aircraft. Only portions of total flights are shown. The colors indicate pressure altitudes of the trajectories (a) 1 April 2008, (b) 5 April 2008, (c) 4 April 2008, (d) 9 April 2008, (e) 4 April 2008, and (f) 12 April 2008. Trajectories for all ARCTAS aircraft flights are available at http://fuelberg.met.fsu.edu/research/arctas/traj/traj.html.

these highs produces westerly winds on their northern peripheries. The Pacific high, which had been stronger than normal during the spring (Fig. 2), now is near its climatological value (Fig. 14a, b). Its Atlantic counterpart has strengthened and expanded in coverage. The middle latitude storm tracks (white and blue areas) continue to be well defined. The Pacific track extends from Siberia to the Aleutians, not far from its spring location (Fig. 2a). The Atlantic storm track is north of its springtime position, extending from Newfoundland to Scandinavia. Pressures along both tracks are slightly below average, signifying stronger than normal cyclones. The NAO continues to be negative, with values of -1.39 and -1.27 during June and July, respectively. The blue and purple areas over Asia represent low pressure due to the seasonal 

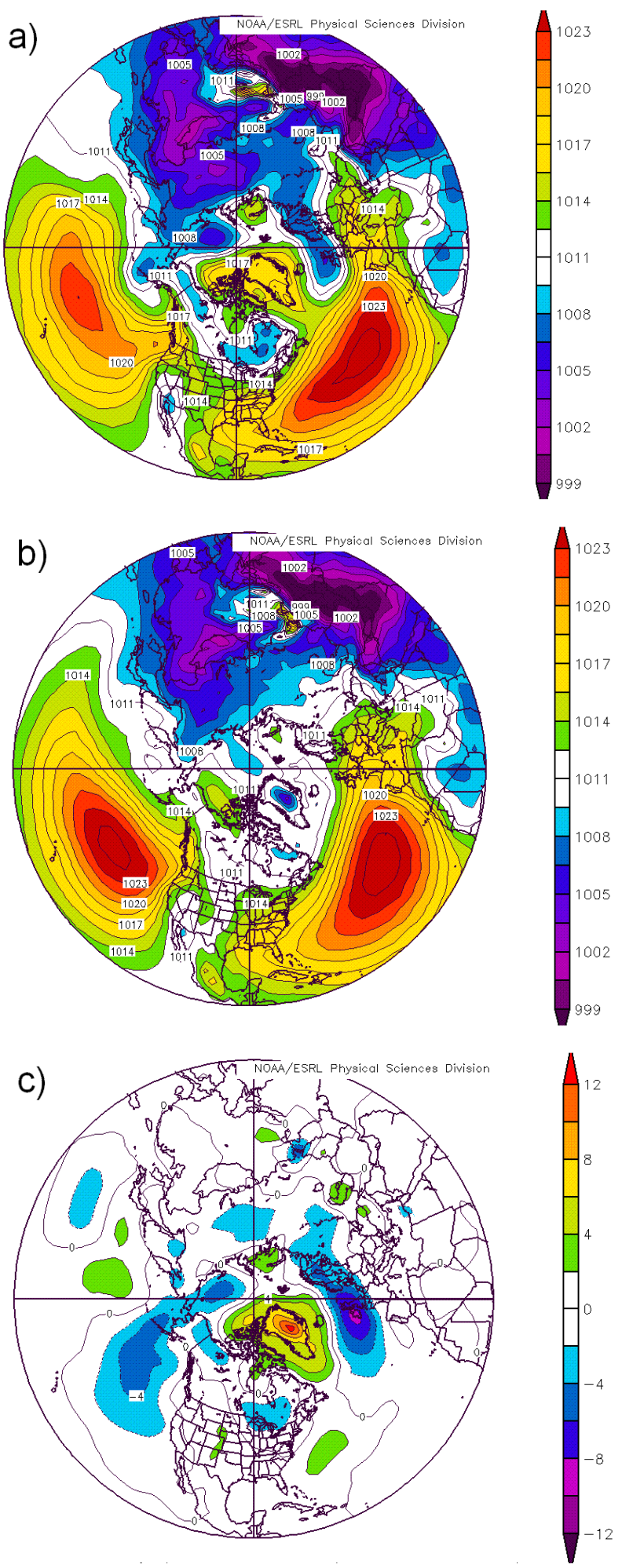

Fig. 14. Mean sea level pressure (hPa) for the period 18 June-13 July 2008. (a) Observed mean, (b) Climatological mean, (c) Departure from climatological mean. Analyses were prepared from the web site of the Climate Diagnostics Center (http://www.cdc.noaa. gov). monsoon. Although the location of the arctic front continued to exhibit day-to-day variations, it had retreated farther north to $\sim 70^{\circ} \mathrm{N}$ during ARCTAS-B (not shown).

The sinusoidal height and flow patterns at $500 \mathrm{hPa}$ during ARCTAS-B (Fig. 15a) also reflect typical seasonal changes. Strong height gradients, and therefore strong westerly flow, have retreated to the middle latitudes, although locations of troughs and ridges generally are consistent with climatology (Fig. 15a, b). The only major climatological departure is the location of the polar low (Fig. 15c). Normally centered over the North Pole, it is displaced north of Eastern Siberia during the 2008 period. At $300 \mathrm{hPa}$ (Fig. 16), the jet stream has retreated north into the middle latitudes and has two components over Asia. The southern segment passes over Central Asia and is near the climatological position (Fig. 16b), while the component over extreme Northern Asia is $\sim 10 \mathrm{~m} \mathrm{~s}^{-1}$ stronger than its weak climatological counterpart. Speed anomalies in other portions of the Northern Hemisphere generally are less than $6 \mathrm{~m} \mathrm{~s}^{-1}$.

\subsection{Example cases}

The NASA DC-8 sampled air pollution over California (the CARB Experiment) during the first week of the summer campaign (18-24 June 2008). The weather over California at this time is dominated by high pressure centered over the $\mathrm{Pa}$ cific (Fig. 17a). Middle latitude cyclones are relatively weak over the entire Northern Hemisphere during CARB, and most follow the expected west to east track at relatively high latitudes. A notable exception (Fig. 17a) is an intense cyclone that develops near the coast of Siberia and then moves slowly toward the North Pole before dissipating. Thus, middle latitude cyclones affect the Arctic even during summer.

Cyclone activity increases in number and intensity during the following three weeks when the ARCTAS aircraft were in Alaska (Fig. 17b-d). Most of the systems either form over Northern Russia and then cross the North Pacific or form over Canada and cross the North Atlantic. They have little influence on California. Some cyclones are quite strong, with Central pressures less than $990 \mathrm{hPa}$. One cyclone passes almost directly over the North Pole (Fig. 17d), similar to the system during the first week of the summer campaign (Fig. 17a).

Unlike the spring campaign, the middle latitude cyclones during ARCTAS-B produce widespread thunderstorms over Southern Canada. The vigor of some storms is indicated by the amount of lightning that they produce. Some areas have as many as 2500 cloud-to-ground (CG) flashes over $1^{\circ} \times 1^{\circ}$ areas during the overall CARB and ARCTAS-B period (Fig. 18a). The day having the most $\mathrm{CG}$ lightning (6 July 2008) records $\sim 30000$ flashes (Fig. 17b), mostly over Southern Alberta and Saskatchewan. Early July is the period of most intense CG lightning (Fig. 18c) over North America north of $50^{\circ} \mathrm{N}$. Lightning is indicative of strong updrafts within a storm that produce a vertical profile of liquid and 

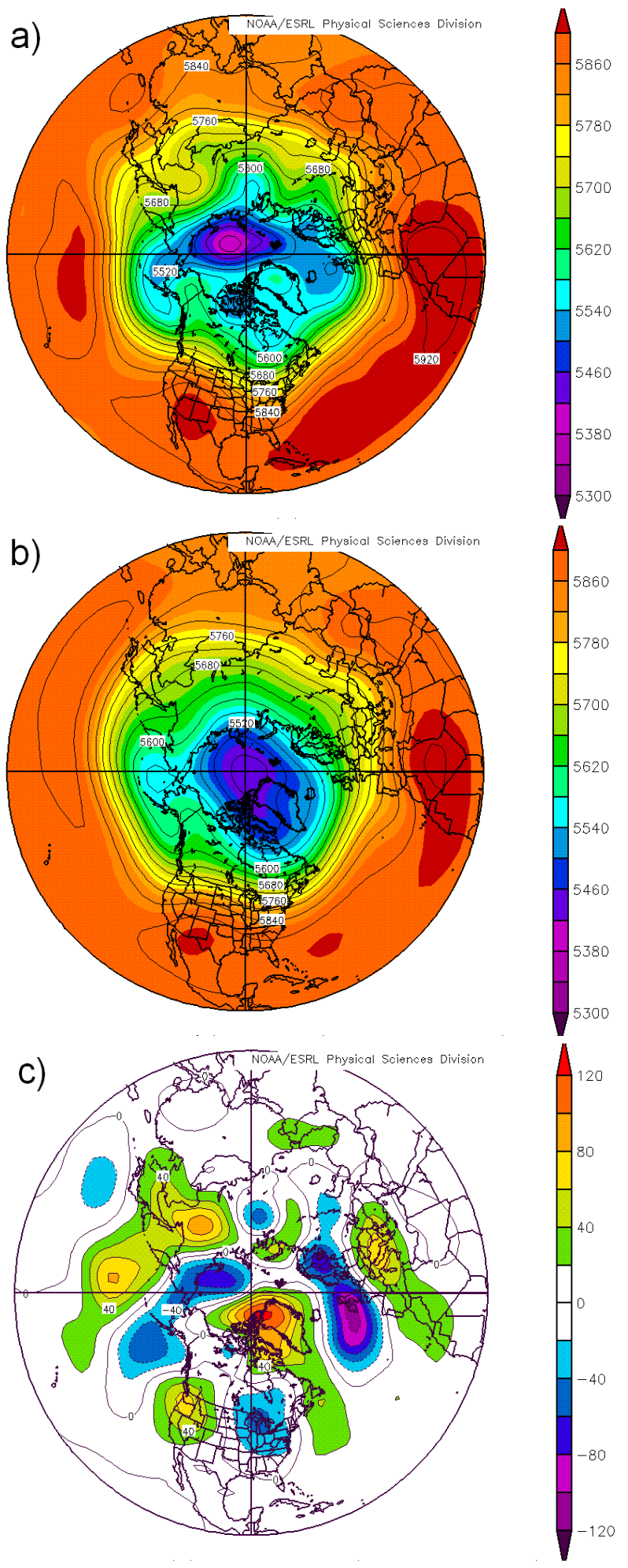

Fig. 15. $500 \mathrm{hPa}$ heights for the period 18 June-13 July 2008. (a) Observed mean, (b) Climatological mean, (c) Departure from climatological mean. Analyses were prepared from the web site of the Climate Diagnostics Center (http://www.cdc.noaa.gov/cgi-bin/ data/getpage.pl). various types of ice particles that is conducive to electrical charging (e.g., Williams, 1989). The strong updrafts and downdrafts can quickly carry surface pollutants aloft, and transport cleaner air toward the surface (e.g., Halland et al., 2009). Lightning also is an important source of nitrogen oxides $\left(\mathrm{NO}_{\mathrm{x}}\right)$ in the middle and upper troposphere that play a direct role in producing tropospheric ozone (e.g., Pickering et al., 1998; DeCaria et al., 2005; Ott et al., 2007; Schumann and Huntrieser, 2007).

Widespread fire activity occurs during CARB and ARCTAS-B, with most fires located at higher latitudes than during spring (Jacob et al., 2009). Many fires were located poleward of $60^{\circ} \mathrm{N}$ over Canada, Alaska, and Eurasia. The mission aircraft made a special effort to sample smoke from the fires over Canada and Northern California, designing flights both within, upwind, and downwind of the fire areas. Fires in the Saskatchewan area of Western Canada on 29 June are shown in Fig. 19. One should note the cauliflower shaped turrets of dark smoke that extend upward from the fires and resemble the water based white cumulus clouds. These are examples of pyrocumulus clouds that have been described by Fromm et al. $(2005,2008)$ in numerous papers (e.g., 2005, 2008). Although pyroconvection has been observed to penetrate the stratosphere, those in Fig. 19 extend only to $\sim 2000 \mathrm{ft}(\sim 0.6 \mathrm{~km})$. The lead author can attest to the strength of the updrafts in both the cumulus and pyrocumulus. The trajectory and FLEXPART data that follow reveal that smoke from some fires in Asia and Canada is transported to the high Arctic latitudes. Paris et al. (2009) also describe this poleward transport during ARCTAS-B.

\subsection{Transport to the Arctic}

Our procedures for determining transport to the Arctic during the summer campaign were identical to those used during spring (Sect. 3.3). Table 1 shows that $18 \%$ of the trajectories released over most of the Northern Hemisphere (Fig. 1) reach $70^{\circ} \mathrm{N}$ within 10 days, slightly less than during the spring campaign (20\%). Barrie (1986) argued that maximum transport to the Arctic occurs during winter, and current results are consistent with his finding. $20 \%$ of the trajectories released at $300 \mathrm{hPa}$ make the successful journey, while $15 \%$ of the surface releases do so. Compared to spring (Table 2), more trajectories arrive at pressures less than $400 \mathrm{hPa}(46.0 \%$ vs. $42.7 \%)$, and fewer arrive in the lower troposphere $(17.8 \%$ vs. $20.9 \%$ ).

Parcels released near the surface enter the Arctic $\left(70^{\circ} \mathrm{N}\right)$ in four major regions (Fig. 20a). The Northern Alaska and Northeastern Canada/Bering Sea regions are similar to those observed during the spring (Fig. 7a). The region over Northern Scandinavia does not have a spring counterpart, while the maximum over Central Russia may be a westward displacement of the Eastern European and Western Russian maxima observed during spring. The general similarities between spring and summer are not surprising since the 

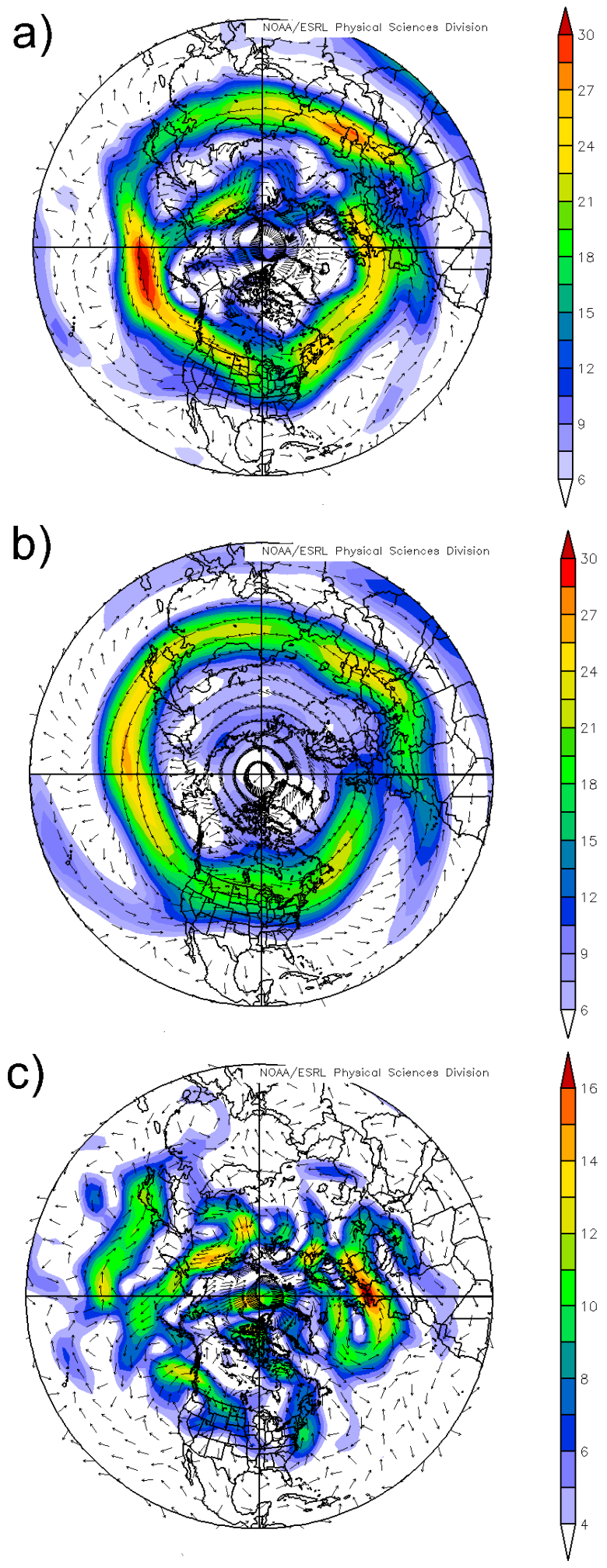

Fig. 16. Average vector winds and isotachs $\left(\mathrm{m} \mathrm{s}^{-1}\right)$ at $300 \mathrm{hPa}$ for the period 18 June-13 July 2008. (a) Observed mean, (b) Climatological mean, c) Departure from climatological mean. Analyses were prepared from the web site of the Climate Diagnostics Center (http://www.cdc.noaa.gov).

middle latitude storm tracks had not changed greatly during the intervening two months. The arrival pressures at $70^{\circ} \mathrm{N}$ (Fig. 20b) continue to show large variability, with values ranging from $1000-200 \mathrm{hPa}$. This panel and the release locations for trajectories reaching the Arctic (Fig. 20c) show that relatively few surface based parcels originating south of $40^{\circ} \mathrm{N}$ reach the Arctic. This is consistent with climatology in that the jet stream moves northward between the spring and summer missions and that wind speeds generally are slower during summer (Figs. 4, 16). The most common paths taken by trajectories reaching the Arctic (Fig. 20d) are near Alaska, over Scandinavia, and Northeastern Russia. The blocking effect of Greenland's high terrain again is evident. Some of the paths are near areas of major summertime biomass burning (Fig. 11b)

Trajectories released at $500 \mathrm{hPa}$ arrive at $70^{\circ} \mathrm{N}$ in four major regions (Fig. 21a) - Northern Alaska, Baffin Island and Greenland, Scandinavia, and North Central Asia. The first two areas are similar to those during spring (Fig. 8a); however, Scandinavia and North Central Asia reflect the different middle tropospheric flow regimes occurring during the warm season. The arrival pressures at $70^{\circ} \mathrm{N}$ again show a wide distribution (Fig. 21b). As noted for the near surface releases, only trajectories departing from $\sim 40^{\circ} \mathrm{N}$ reach the Arctic within 7 days (Fig. 21c). Many trajectories reaching the Arctic during summer pass over Alaska (Fig. 21d), with secondary maxima near Baffin Island and Scandinavia. Finally, the results for trajectory releases at $300 \mathrm{hPa}$ (Fig. 22) reveal similar entrance locations, initiation locations, and pathways as those at $500 \mathrm{hPa}$ (Fig. 21). However, one should note that no trajectories released at $300 \mathrm{hPa}$ arrive at $70^{\circ} \mathrm{N}$ at pressures greater than $625 \mathrm{hPa}$.

FLEXPART simulations reveal the sources and paths of anthropogenic and biomass burning CO during ARCTASB (Fig. 23). We have prepared statistics on the fates of the many biomass burning plumes during ARCTAS-B by using forward trajectories and FLEXPART analyses from the fire locations. These detailed results will be presented in a future manuscript.

Figure 23a shows three major regions of anthropogenic pollution at $2 \mathrm{~km}$ on 25 June. Pollution streaming northward from Europe and Western Asia extends as far north as $85^{\circ} \mathrm{N}$, while a large area of anthropogenic $\mathrm{CO}$ from the Northeast US is moving toward the northeast. Finally, the anthropogenic pollution over Eastern Asia first was noticed at $2 \mathrm{~km}$ on June 15 near Beijing and North Korea. Since winds were light in the area, the area moved little, but gradually grew in size and $\mathrm{CO}$ concentration. The patterns of anthropogenic case at $2 \mathrm{~km}$ on July 3 at $2 \mathrm{~km}$ are especially interesting (Fig. 23b). A relatively weak and narrow plume from the Northeast US travels eastward across the Atlantic Ocean, merges with European anthropogenic emissions. and then begins to rotate cyclonically around Iceland and Southern Greenland, reaching $\sim 75^{\circ} \mathrm{N}$. 

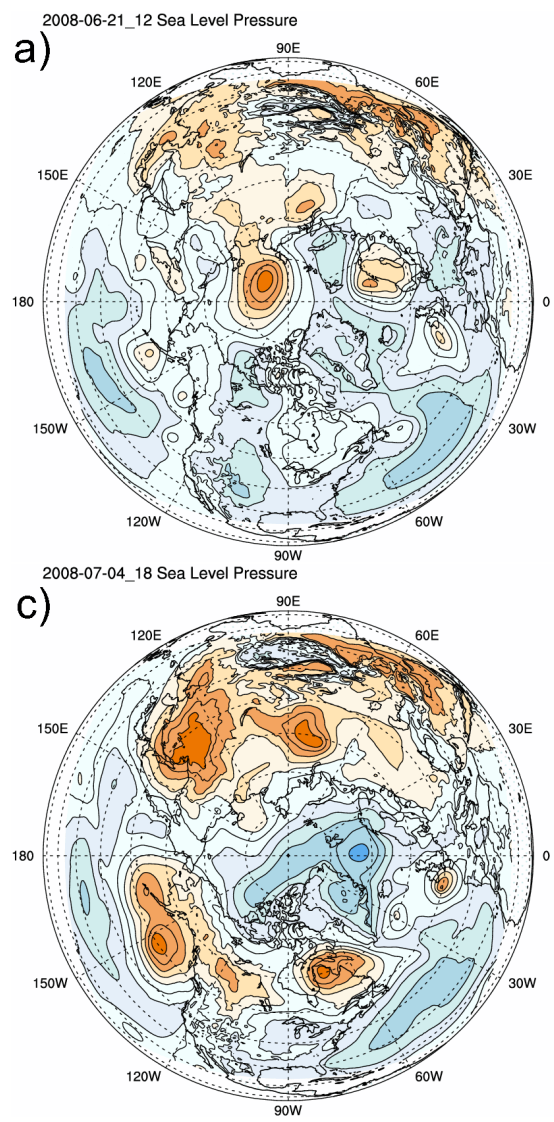
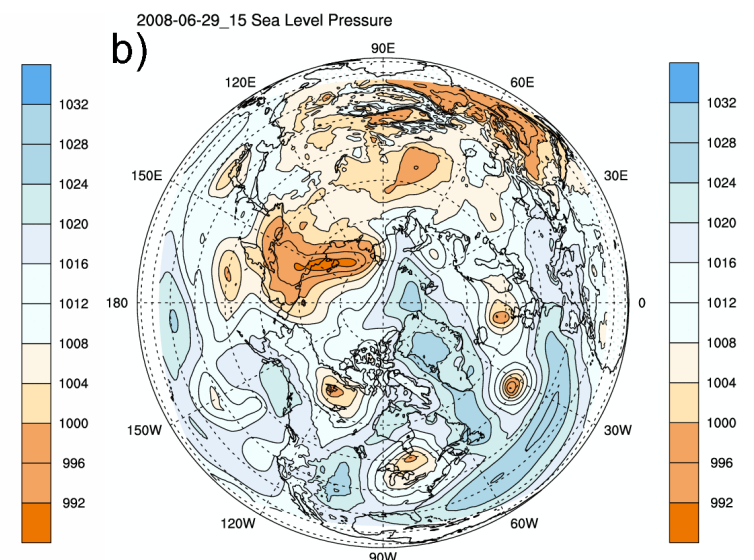

d)
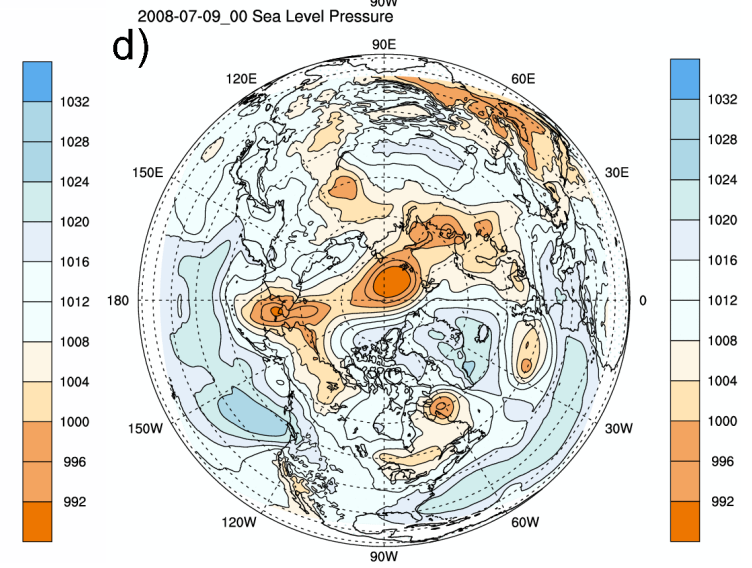

Fig. 17. Surface pressure analyses at $4 \mathrm{hPa}$ intervals from the FSU WRF runs. (a) 21 June 2008, (b) 29 June 2008, (c) 4 July 2008, and (d) 9 July 2008. Analyses for other days available at http://fuelberg.met.fsu.edu/research/arctas/traj/traj.html.

Examples of biomass burning $\mathrm{CO}$ plumes are depicted in Fig. 23c, d. The area of $\mathrm{CO}$ at $2 \mathrm{~km}$ on 7 July (Fig. 23c) is located near a large area of fires near Beijing (Fig. 10b) The plume moves eastward and splits into two, one over the North Pacific and a second that moves northeastward toward the North Pole. Fires over Canada and Northern California produce weaker $\mathrm{CO}$ plumes that merge near the Great Lakes and pass offshore near the Canadian Maritimes. Although the pollution does not reach the Arctic, it is a good example of how biomass burning by-products can travel long distances and reach $\sim 55^{\circ} \mathrm{N}$. Figure $23 \mathrm{~d}$ also is for 7 July, but at $9 \mathrm{~km}$ altitude. The $\mathrm{CO}$ from fires near Beijing is not evident at $9 \mathrm{~km}$ until 2 days after detection at $2 \mathrm{~km}$ since the pollution must be lofted an additional $7 \mathrm{~km}$. A portion of the plume passes over the North Pole on 4 July (not shown), while the remaining portion heads east across the Pacific and reaches Northern Washington on 5 July (not shown). By 7 July (Fig. 23d), this area extends as far east as the Great Lakes. Meanwhile, the $\mathrm{CO}$ still being produced by the fires near Beijing travels to $\sim 85^{\circ} \mathrm{N}$. The $\mathrm{CO}$ pattern in Fig. 23d closely corresponds to the flow pattern at $300 \mathrm{hPa}$ (not shown) - a high pressure ridge axis oriented from the pole to extreme Eastern Siberia and a deep trough located south of the Aleu- tians. This is a prime example of how synoptic scale wind patterns affect the transport of pollution.

Ten day back trajectories from the aircraft tracks indicate the wide variety of air histories that were sampled in situ. Figure 24a summarizes trajectories of the transit flight from Cold Lake, Alberta to the Nevada-California border. Four pathways are evident as the flight heads south - originating over Northern Asia, near Japan, the Central Pacific Ocean, and off the coast of Baja California. Examples during the CARB mission are shown in Fig. 24b-c; both from the 22 June flight. These offshore flight segments show the sources of air entering California, but avoid the complex mesoscale circulations located onshore (e.g., mountain/valley breezes, sea breezes, etc.). The Northernmost set of trajectories (Fig. 24b) begins near Japan and the Kamchatka Peninsula at $\sim 500 \mathrm{hPa}$, circles around a middle tropospheric low, and then travel east of high pressure near the Aleutians while descending to $\sim 700 \mathrm{hPa}$ where they are sampled by the DC- 8 . The southern set of trajectories on 22 June (Fig. 24c) follows a very different route, moving northward at an almost constant altitude of $\sim 700 \mathrm{hPa}$. 


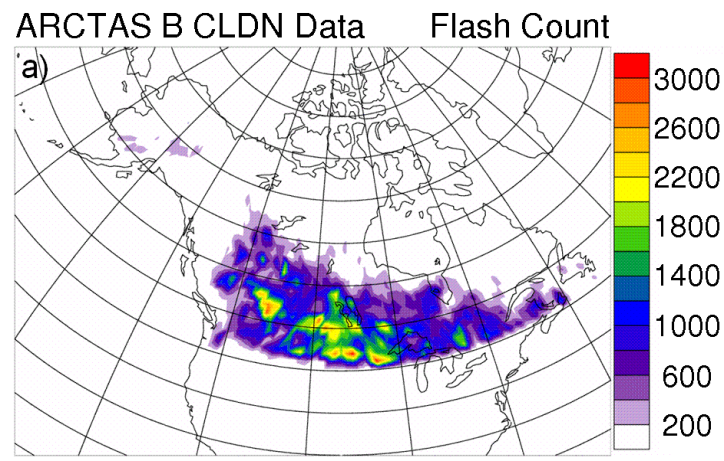

Stroke Locations July 6, 2008

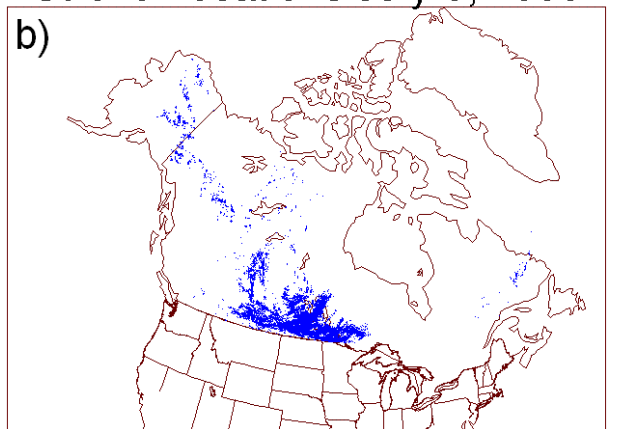

Summer ARCTAS

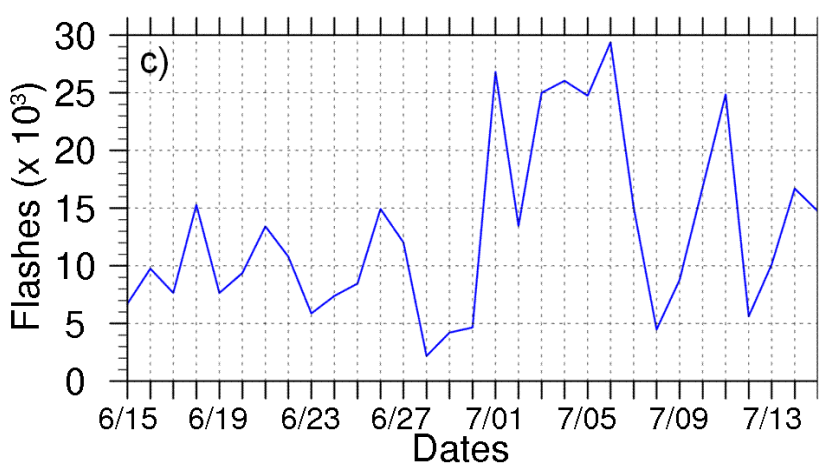

Fig. 18. (a) Cloud-to-ground lightning flash locations and counts on a $1^{\circ} \times 1^{\circ}$ grid north of $50^{\circ} \mathrm{N}$ during the CARB and ARCTASB periods. (b) Lightning strike locations north of $50^{\circ} \mathrm{N}$ on 6 July 2008, the day with the greatest lightning in Alaska and Canada. (c) Time series of cloud-to-ground flash counts north of $50^{\circ} \mathrm{N}$ during the CARB and ARCTAS-B periods.

Figure $24 \mathrm{~d}-\mathrm{f}$ shows trajectories when the DC- 8 flew in the Arctic region. The flight on 8 July (Fig. 24d) crossed a high pressure ridge axis at altitudes between $300-400 \mathrm{hPa}$. Some trajectories reach the DC- 8 from the east looping around a mid-level low pressure area over the Canadian Maritimes. The other trajectories arrive from the west, beginning over the Sea of Japan at low altitudes (near $950 \mathrm{hPa}$ ) near a middle latitude cyclone, and then quickly ascended to the middle and upper troposphere where they are sampled. This is a prime example of how the warm conveyor belt (WCB) of a middle latitude cyclone can quickly lift low level parcels to
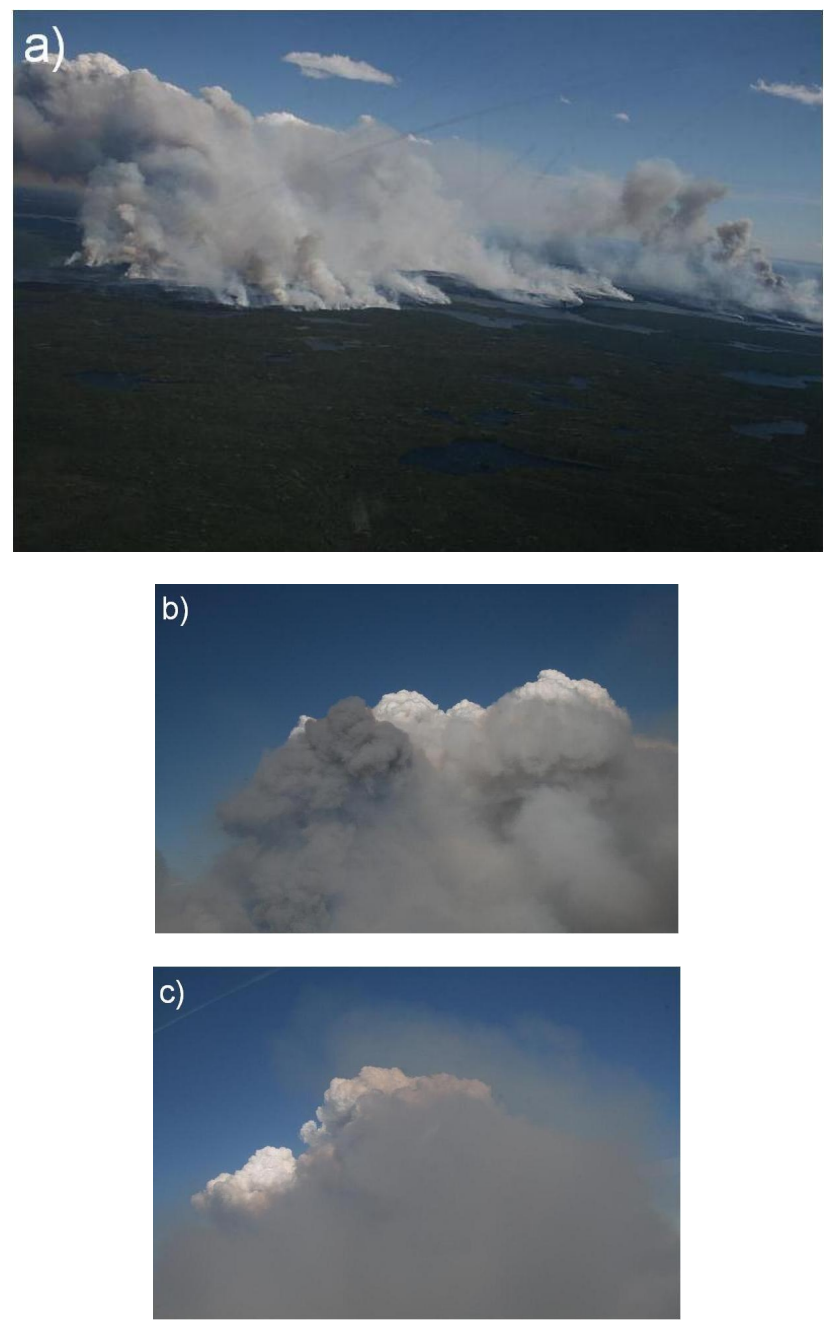

Fig. 19. Photos of fires and pyrocumulus taken from the cockpit of the DC- 8 by the lead author on 29 June when the aircraft was flying at $\sim 0.5 \mathrm{~km}(\sim 1700 \mathrm{ft})$. Additional photos of phenomena observed during CARB and ARCTAS are at http://fuelberg.met.fsu. edu/gallery/arctas/.

higher altitudes (Fig. 5). Since widespread fire activity is occurring west of the Sea of Japan, it is likely that the WCB carried this smoke laden air to near the North Pole. Figure 24e illustrates air near California being transported to near Hudson Bay. Finally, Fig. 24f depicts trajectories from one of the sorties to the North Pole when the aircraft was near $350 \mathrm{hPa}$. Some parcels originate over Northern Siberia at high altitudes, while others originate at lower altitudes north and east of the low near the Sea of Japan.

\section{Summary and conclusions}

The ARCTAS mission was conducted during April and JuneJuly 2008 by the Global Tropospheric Chemistry and the Radiation Sciences Programs of the US National Aeronautics 

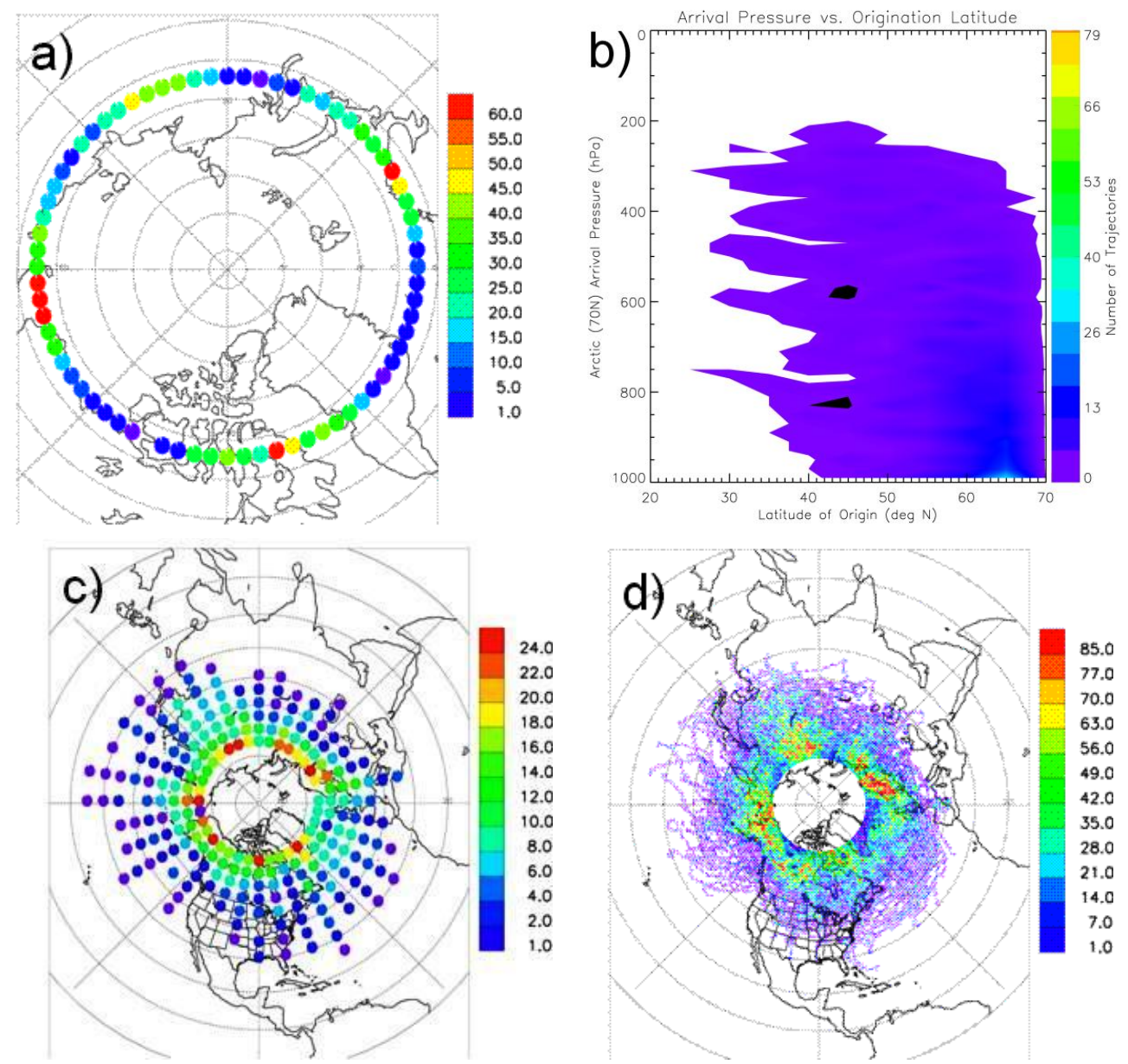

Fig. 20. a) Numbers of 10 day forward trajectories reaching $70^{\circ} \mathrm{N}$. Values are given at intervals of $5^{\circ}$ longitude. The trajectories were released at the surface at 00:00 UTC each day during the CARB and ARCTAS-B missions on a $5^{\circ}$ latitude by $10^{\circ}$ longitude grid (11016 total grid points) encompassing most of the Northern Hemisphere (Fig. 1). (b) Pressure altitudes of those trajectories arriving at $70^{\circ} \mathrm{N}$ as a function of their latitude of release. (c) Initial locations and numbers of the trajectories reaching $70^{\circ} \mathrm{N}$ during the 10 day period. Numbers of trajectories passing over $1^{\circ} \times 1^{\circ}$ grid boxes during their paths to $70^{\circ} \mathrm{N}$.

and Space Administration (NASA). This paper has summarized meteorological conditions during ARCTAS, including large-scale flow patterns, their departures from climatology, distributions of lightning and wildfires, transport pathways to the Arctic, and the origins and paths taken by air sampled by the ARCTAS aircraft. Major conclusions for the April (ARCTAS-A) period are listed below.

- The tracks of middle latitude cyclones over Eastern Asia and the North Pacific were displaced north of their climatological position. Many cyclones formed near Japan and over the Lake Baikal region of Russia. These storms followed a more northerly course than usual. Although it is more common for storms to pass over the Gulf of Alaska and then dissipate, many of the ARCTAS-A cyclones dissipated over Northern Alaska. Cyclone activity over the North Atlantic was less common than over the Pacific, with relatively few storms forming over the east coast of North America. Conversely, cyclogenesis over the Eastern North Atlantic was more common.

- The easterly flowing jet stream over the North Pacific was displaced north of its climatological position, consistent with the higher latitude cyclones. The jet stream was weaker than normal over the North Atlantic.

- The North Atlantic Oscillation was in a negative phase during ARCTAS-A, indicating that heights and pressures were above normal across the high latitudes of the North Atlantic, and below normal over the Central North Atlantic, Eastern US, and Western Europe. Negative values of the NAO index have been associated with diminished pollution transport to the Arctic compared to the positive phase (Eckhardt et al., 2003; Duncan and Bey, 2004). 

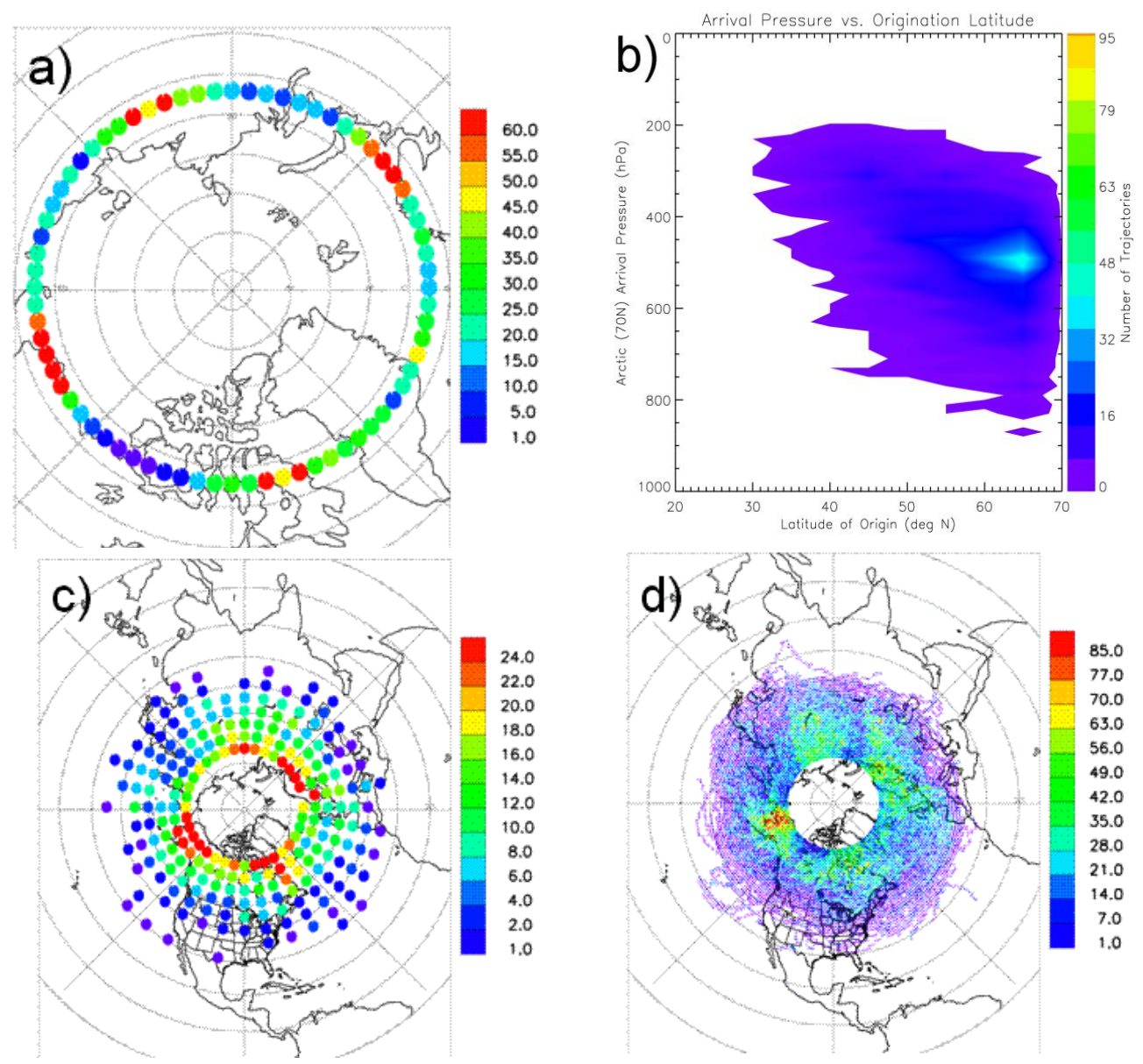

Fig. 21. As in Fig. 20, but for trajectories released at $500 \mathrm{hPa}$.

- Approximately $20 \%$ of trajectories released from sites over much of North America reached $70^{\circ} \mathrm{N}$ within 10 days. Releases near the surface entered the Arctic (i.e., at $70^{\circ} \mathrm{N}$ ) at three preferred regions - Eastern Europe and Western Asia, near Baffin Island and Greenland, and near Alaska. Trajectories released at 500 and $300 \mathrm{hPa}$ entered the Arctic mostly north of Alaska and near Baffin Island/Greenland. These findings contrast with previous studies indicating that Eurasia is the dominant source of Arctic pollution during winter and early spring, with only weak transport from North America (e.g., Stohl, 2006; Klonecki et al., 2003; Barrie 1986; Raatz and Shaw, 1984). However, current results are consistent with those of Eckhardt et al. (2003) who related Arctic transport to phases of the NAO. Seasonal transitions may also be a factor in these different results.

- Widespread agricultural and forest fires occurred over Southern Russia during ARCTAS-A, and their occurrence was earlier than normal. A recent study of fires in Eastern Europe during Spring 2006 (Stohl et al., 2007) concluded that biomass burning has been under- estimated as a source of Arctic aerosols and trace gases. Their importance during April 2008 is discussed by Warneke et al. (2009). Our own Lagrangian particle dispersion modeling (FLEXPART) indicates that the Russian fires were an important source of pollution during ARCTAS-A, with some of the biomass burning plumes reaching the North Pole.

- Backward trajectories indicated that the three ARCTAS aircraft sampled air from a wide variety of locations and that had followed a myriad of paths and encountered many types of meteorological conditions.

Major conclusions for the CARB and ARCTAS-B missions during June and July include the following:

- There continued to be abundant middle latitude cyclone activity during the summer, with some cyclones being very intense. The Pacific storm track extended from Siberia to the Aleutians, not far from its spring location, while the Atlantic track was north of its springtime position, extending from Newfoundland to Scandinavia. 

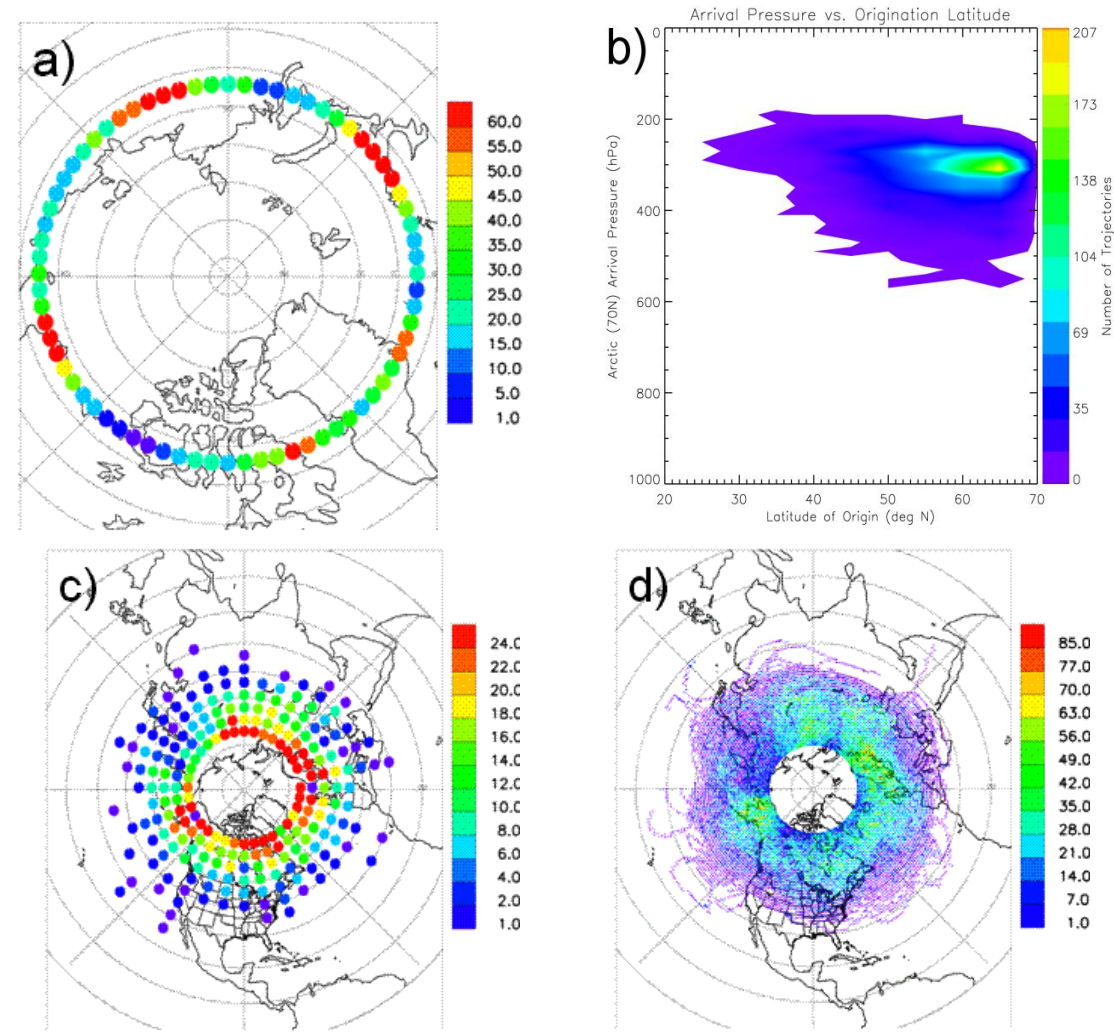

Fig. 22. As in Fig. 20, but for trajectories released at $300 \mathrm{hPa}$.
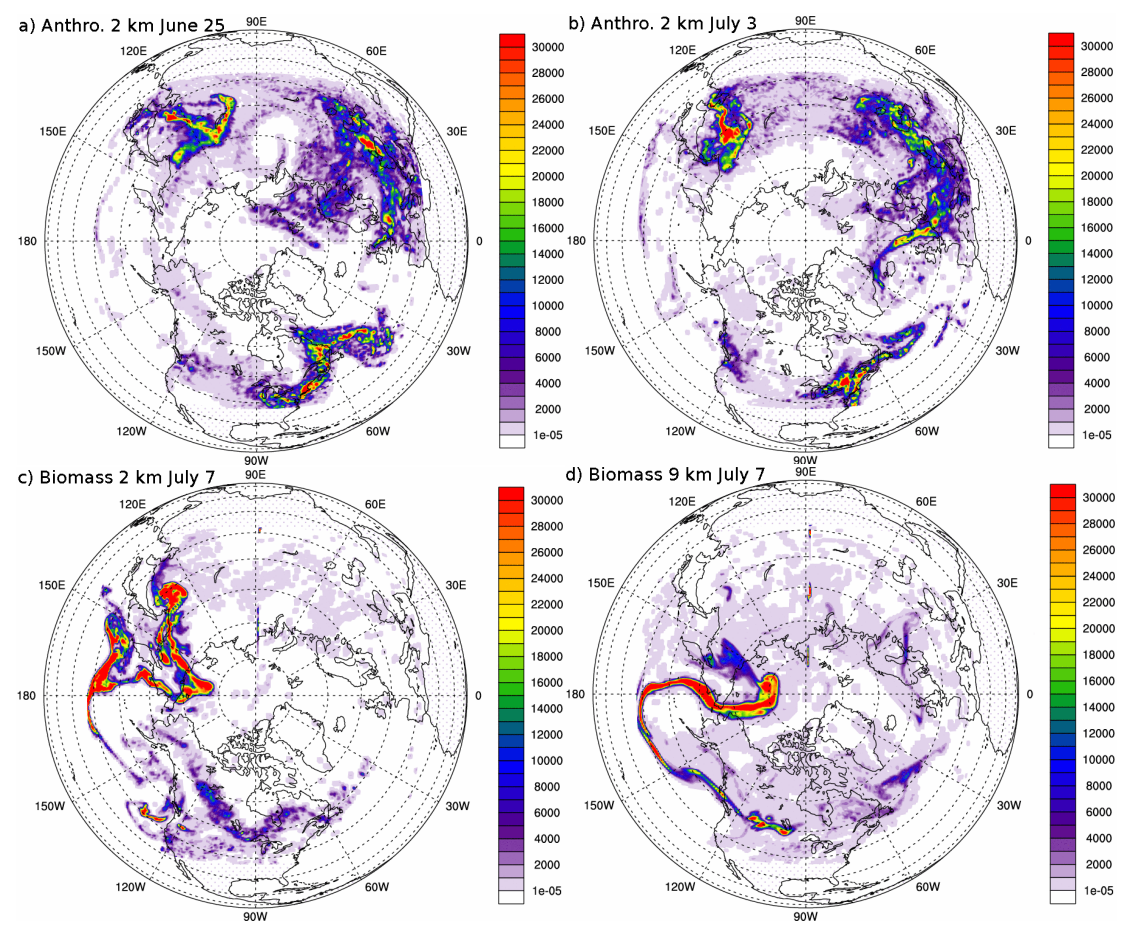

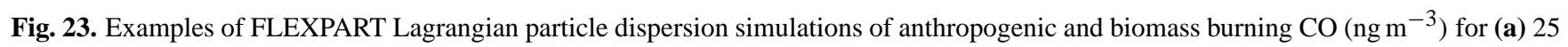
June 2008 at $2 \mathrm{~km}$, (b) 3 July 2008 at $2 \mathrm{~km}$, (c) 7 July 2008 at $2 \mathrm{~km}$, and (d) 7 July 2008 at $9 \mathrm{~km}$. Simulations for all flights are available at http://fuelberg.met.fsu.edu/research/arctas/traj/traj.html. 

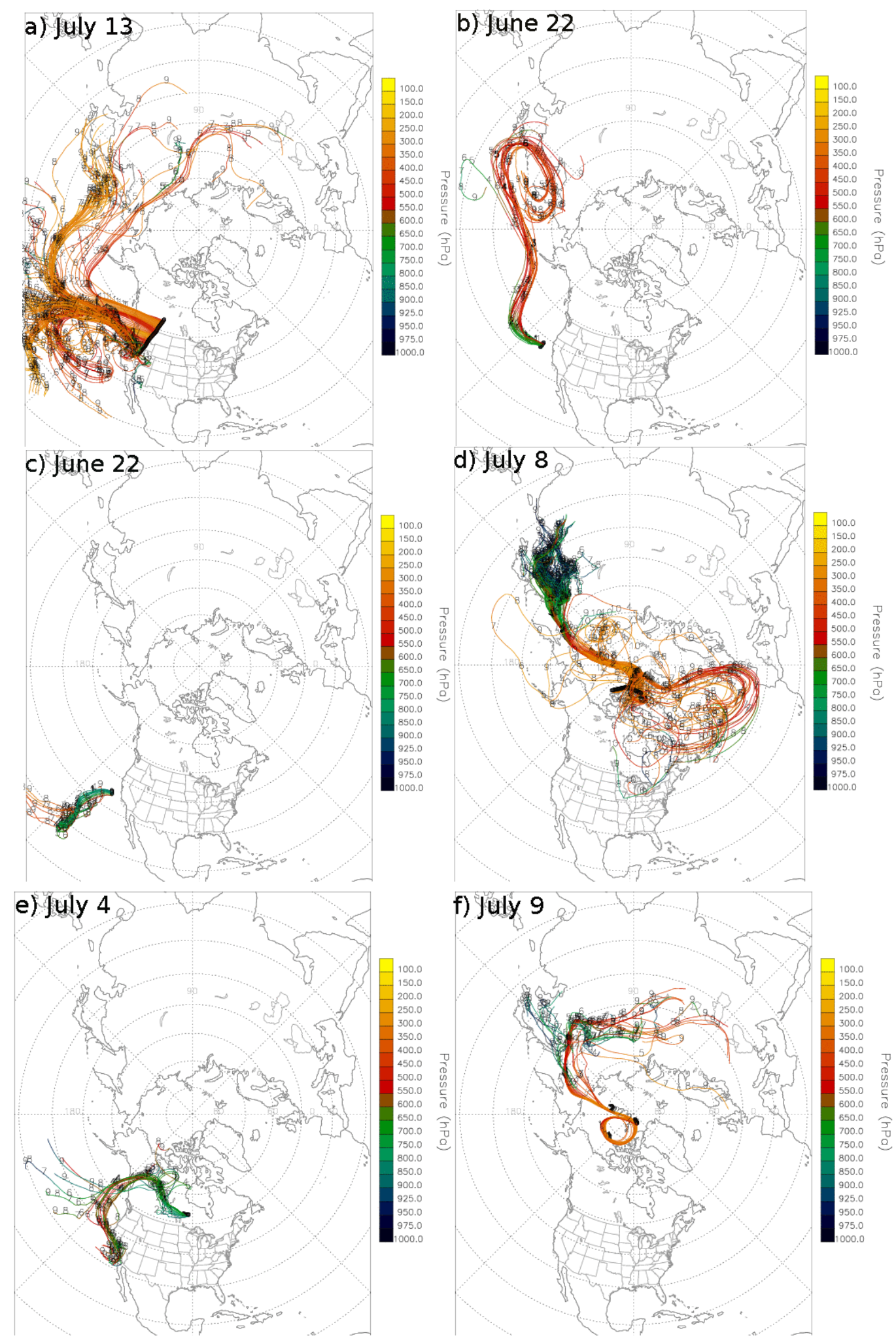

Fig. 24. 10 day backward trajectories showing examples of air sampled by the DC-8 aircraft. Only portions of total flights are shown. The colors indicate pressure altitudes of the trajectories (a) 13 July 2008, (b) 22 June 2008, (c) 22 June 2008, (d) 8 July 2008 , (e) 8 July 2008 , (f) 4 July 2008, (g) 5 July 2008, (h) 9 July 2008. Trajectories for all ARCTAS aircraft are available at http://fuelberg.met.fsu.edu/research/ arctas/traj/traj.html. 
- The NAO continued to be negative, more negative than during April.

- In the middle and upper troposphere, the only major climatological departure was the location of the polar low. Normally centered over the North Pole, it was displaced to north of Eastern Siberia. At $300 \mathrm{hPa}$, the jet stream had retreated north into the middle latitudes. The jet over Asia exhibited a split configuration. The southern component was near the climatological position, while the northern component had no climatological counterpart.

- There was abundant lightning over South Central Canada during the summer period. The lightning produced wildfires, most abundant over Saskatchewan, that were sampled extensively by the ARCTAS aircraft. The fires over Asia continued, and were even more widespread than during April. A major area of fires was located near and west of Beijing, with many of their resulting plumes entering the ARCTAS-B domain and even reaching the North Pole.

- Trajectories released near the surface over much of the Northern Hemisphere entered the Arctic in four regions. The Northern Alaska and Northeastern Canada/Bering Sea regions are similar to those observed during the spring campaign. The region over Northern Scandinavia did not have a spring counterpart, while the secondary summer maximum over Central Russia may be a westerly displacement of the area over Eastern Europe and Central Russia during spring. Unlike the spring period, summer trajectories released from 500 and $300 \mathrm{hPa}$ arrived at $70^{\circ} \mathrm{N}$ near the same four major regions as the surface releases - Northern Alaska, Baffin Island and Greenland, Scandinavia, and North Central Asia.

- FLEXPART analyses revealed numerous cases when anthropogenic and biomass burning tracers were transported to near the North Pole. Backward trajectories revealed that some of these cases were sampled by the ARCTAS aircraft, in addition to air that came from numerous other sources.

ARCTAS was a major success from a meteorological perspective. There was frequent transport to the Arctic, and the three ARCTAS aircraft sampled air that originated from a multitude of sources and had experienced a host of atmospheric conditions. The POLARCAT mission had similar successes, with numerous studies presented in this special issue. Detailed chemical and meteorological analyses of the ARCTAS periods will provide a wealth of information about the factors driving changes in the Arctic's atmospheric composition and climate. It is one more example of the critical role that meteorology plays in atmospheric transport.
Acknowledgements. This research was sponsored by NASA's Global Tropospheric Chemistry Program through Grant NNX08AH72G to Florida State University. The ARCTAS flights were sponsored by NASA, while flights in and near California were sponsored by the California Air Resources Board (CARB). We appreciate the assistance of the many individuals who made ARCTAS and CARB a success - the ground crew, pilots, supporting staff, and other members of the ARCTAS Science Team.

Edited by: A. Stohl

\section{References}

Bader, M. J., Forbes, G. S., Grant., J. R., Lilley, R. B. E., and Waters, A. J.: Images in weather forecasting - A practical guide for interpreting satellite and radar imagery, Cambridge University Press, 1995.

Barnston A. G. and Livezey, R. E.: Classification, seasonality and persistence of low-frequency atmospheric circulation patterns, Mon. Weather Rev, 115, 1083-1126, 1987.

Barrie, L. A.: Arctic air pollution - An overview of current knowledge, Atmos. Env., 20, 643-663, 1986.

Barrie, L. A. and Hoff, R. M.: Five years of air chemistry observations in the Canadian Arctic, Atmos. Env., 19, 1995-2010, 1985.

Barrie, L. A., Bottenheim, J. W., and Hart, W. R.: Polar Sunrise Experiment 1992 (PSE 1992): Preface, J. Geophys. Res., 99, 25313-25314, 1994.

Bradley, R. S., Keiming, F. T., and Diaz, H. F.: Climatology of surface-based inversions in the North American Arctic, J. Geophys. Res., 97, 15699-15712, 1992.

Bromwich, D. H., Hines, K. M., and Bai, L.-S.: Development and testing of Polar Weather Research and Forecasting Model: 2. Arctic Ocean. J. Geophys. Res., 114, D08122, doi:10.1029/2008JD010300, 2009.

Browning, K. A. and Monk, G. A.: A simple model for the synoptic analysis of cold fronts, Q. J. Roy. Meteorol. Soc, 100, 435-452, 1982.

Browning, K. A. and Roberts, N. M.: Structure of a frontal cyclone, Q. J. Roy. Meteorol. Soc., 120, 1535-1557, 1994.

Burrows W. R., and P. King, Neuro-statistical models for predicting lightning occurrence in Canada: Climatology and potential predictors. Proc. 2000 Int. Lightning Detection Conf., Tucson, AZ, Global Atmospherics, Inc., Paper 15, available from Vaisala, Inc., 2705 E. Medina, Tucson, AZ 85706, USA, 2000.

Burrows W. R., Lewis, P.J., Kochtubajda, B., Snyder, B., and Turcotte, B., Lightning occurrence patterns over Canada and adjacent United States from lightning detection network observations, Atmos.-Ocean, 40, 59-80 2002.

Carlson, T. N.: Mid-Latitude Weather Systems, American Meteorological Society, Boston, USA, 1998.

Carlson, T. N.: Speculations on the movement of polluted air to the Arctic, Atmos. Env., 15, 1473-1477, 1981.

Cooper, O., Moody, J. L., Parrish, D. D., Trainer, M., Holloway, J. S., Huebler, G., Fehsenfeld, F. C., and Stohl, A.: Trace gas composition of mid-latitude cyclones over the western North Atlantic Ocean: A seasonal comparison of $\mathrm{O} 3$ and CO. J. Geophys. Res., 107, 4056, doi:10.1029/2001JD000902, 2002.

Cooper, O., Moody, J., Parrish, D., Trainer, M., Ryerson, T., Holloway, J., Hübler, G., Fehsenfeld, F., Oltmans, S., and Evans, 
M.: Trace gas signatures of the airstreams within North Atlantic cyclones: Case studies from the North Atlantic Regional Experiment (NARE '97) aircraft intensive, J. Geophys. Res., 106(D6), 5437-5456, 2001.

Curry, J. A.: On the formation of continental polar air, J. Atmos. Sci., 40, 2279-2292, 1983.

Curry, J. A.: The contribution of radiative cooling to the formation of cold-core anticyclone, J. Atmos. Sci., 44, 2575-2592, 1987.

Danielsen, E. F.: Stratospheric-tropospheric exchange based on radioactivity, ozone, and potential vorticity, J. Atmos. Sci., 25, 502-518, 1968,

DeCaria, A. J., Pickering, K. E., Stenchikov, G. L., and Ott, L. E.: Lightning-generated $\mathrm{NO}_{\mathrm{x}}$ and its impact on tropospheric ozone production: A three-dimensional modeling study of a Stratosphere-Troposphere Experiment: Radiation, Aerosols, and Ozone (STERAO-A) thunderstorm, J. Geophys. Res., 110, D14303, doi:10.1029/2004JD005556, 2005.

Djuric, D.: Weather Analysis, Prentice-Hall, Englewood Cliffs, NH, USA, 304 pp., 1994.

Duncan, B. N. and Bey, I.: A modeling study of the export pathways of pollution from Europe: Seasonal and interannual variations (1987-1997), J. Geophys. Res., 109, D08301, doi:10.1029/2003JD004079, 2004.

Eckhardt, S., Stohl, A., Wernli, H., James, P., Forster, C., and Spichtinger, N.: A 15-year climatology of warm conveyor belts, J. Climate 17, 218-237, 2004.

Eckhardt, S., Stohl, A., Beirle, S., Spichtinger, N., James, P., Forster, C., Junker, C., Wagner, T., Platt, U., and Jennings, S. G.: The North Atlantic Oscillation controls air pollution transport to the Arctic, Atmos. Chem. Phys., 3, 1769-1778, 2003, http://www.atmos-chem-phys.net/3/1769/2003/.

Fromm, M., Bevilacqua, R., Servranckx, R., Rosen, J., Thayer, J. P., Herman, J., and Larko, D.: Pyro-cumulonimbus injection of smoke to the stratosphere: Observations and impact of a super blowup in northwestern Canada on 3-4 August 1998, J. Geophys. Res., 110, D08205, doi:10.1029/2004JD005350, 2005.

Fromm, M., Torres, O., Diner, Lindsey, D., Vant Hull, B., Servranckx, R., Shettle, E. P., and Li, Z.: Stratospheric impact of the Chisholm pyrocumulonimbus eruption: 1. Earthviewing satellite perspective, J. Geophys. Res., 113, D08202, doi:10.1029/2007JD009153, 2008.

Fuelberg, H. E., Loring, Jr., R. O., Watson, M. V., Sinha, M. C., Pickering, K. E., Thompson, A. M., Sachse, G. W., Blake, D. R., and Schoeberl, M. R.: TRACE-A trajectory intercomparison 2. Isentropic and kinematic methods, J. Geophys. Res., 101, 23927-23939, 1996.

Fuelberg, H. E., Hannan, J. R., van Velthoven, P. F. J., Browell, E. V., Bieberbach, Jr., G., Knabb, R. D., Gregory, G. L., Pickering, K. E., and Selkirk, H. B.: A meteorological overview of the SONEX period, J. Geophys. Res., 105, 3633-3651, 2000.

Generoso, S., Bey, I., Attié, J.-L., and Bréon, F.-M.: A satelliteand model-based assessment of the 2003 Russian fires: Impact on the Arctic region. J. Geophys. Res., 112, D15302, doi:10.1029/2006JD008344, 2007.

Halland, J. J., Fuelberg, H. E., Pickering, K. E., and Luo, M.: Identifying convective transport of carbon monoxide by comparing remotely sensed observations from TES with cloud modeling simulations, Atmos. Chem. Phys., 9, 4279-4294, 2009, http://www.atmos-chem-phys.net/9/4279/2009/.
Hines, K. M. and Bromwich, D. H.: Development and testing of Polar WRF. Part I. Greenland ice sheet meteorology, Mon. Weather Rev., 136, 1971-1989, 2008.

Iversen, T.: On the atmospheric transport of pollution to the Arctic, Geophys. Res. Lett., 11, 457-460, 1984.

Jacob, D. J.: Introduction to Atmospheric Chemistry, Princeton Univ. Press, 266 pp., 1999.

Jacob, D. J., Crawford, J. H., Maring, H., Dibb, J. B., Clarke, A. D., Ferrare, R. A., Hostetler, C. A., Russell, P. B., Singh, H. B., Thompson, A. M., Shaw, G. E., McCauley, E., Pederson, J. R., and Fisher, J. A.: The ARCTAS aircraft mission: Design and execution, Atmos. Chem. Phys. Discuss., 9, 17073-17123, 2009, http://www.atmos-chem-phys-discuss.net/9/17073/2009/.

James, P., Stohl, A., Forster, C., Eckhardt, S., Seibert, P., and Frank, A.: A 15 year climatology of stratosphere-tropospheric exchange with a Lagrangian particle dispersion model: 2. Mean climate and seasonal variability, J. Geophys. Res., 8522, doi:10.1029/2002JD002639, 2003.

Kahn, R. A., Chen, Y., Nelson, D. L., Leung, F.-Y, Li, Q., Diner, D. J., and Logan, J. A.: Wildfire smoke injection heights: Two perspectives from space, Geophys. Res. Lett., 04809, doi:10:1029/2007GL032165, 2008.

Kalnay, E., Kanamitsu, M., Kistler, R., et al.: The NCEP/NCAR 40Year reanalysis project, B. Amer. Meteorol. Soc., 77, 437-431, 1996.

Klonecki, A., Hess, P., Emmons, L., Smith, L., and Orlando, J.: Seasonal changes in the transport of pollutants into the Arctic troposphere-model study, J. Geophys. Res., 8367, doi:1029/2002JD002199, 2003.

Labonne, M., Bréon, F.-M., and Chevallier, F.: Injection height of biomass burning aerosols as seen from a spaceborne lidar, Geophys. Res. Lett., 11806, doi:10:1029/2007GL02931, 2007.

Levine, J. S. (Ed.): Global Biomass Burning, MIT Press, 569 pp., 1991.

Martin, B. D., Fuelberg, H. E., Blake, N. J., Crawford, J. H., Logan, J. A., Blake, D. R., and Sachse, G. W.: Long range transport of Asian outflow to the equatorial Pacific, J. Geophys. Res., 108(D2), 8322, doi:10.1029/2001JD001418, 2002.

Merrill, J. T. and Moody, J. L.: Synoptic meteorology and transport during the North Atlantic Regional Experiment (NARE) intensive: Overview, J. Geophys. Res., 101, 28903-28921, 1996.

Ott, L. E., Pickering, K. E., Stenchikov, G. L., Huntrieser, H., and Schumann, U.: Effects of lightning NOx production during the 21 July European Lightning Nitrogen Oxides Project storm studied with a three-dimensional cloud-scale chemical transport model, J. Geophys. Res., 112, D05307, doi:10.1029/2006JD007365, 2007.

Paris, J.-D., Stohl, A., Nédélec, P., Arshinov, M. Yu., Panchenko, M. V., Shmargunov, V. P., Law, K. S., Belan, B. D., and Ciais, P.: Wildfire smoke in the Siberian Arctic in summer: Source characterization and plume evolution from airborne measurements, Atmos. Chem. Phys., 9, 9315-9327, 2009, http://www.atmos-chem-phys.net/9/9315/2009/.

Pickering, K. E., Wang, Y., Tao, W. K., Price, C., and Muller, J. F.: Vertical distributions of lightning NOx for use in regional and global chemical transport models, J. Geophys. Res., 103, 3120331216, doi:10.1029/98JD02651, 1998.

Orville, R. E., Huffines, G. R., Burrows, W. R., Holle, R. L., and Cummins, K. L.: The North American lightning detection net- 
work (NALDN)—First results: 1998-2000. Mon. Weather Rev., 130, 2098-2109, 2002.

Raatz, W. E.: The climatology and meteorology of Arctic air pollution, in: Pollution of the Arctic Atmosphere, edited by: Sturges, W. T., Elsevier, New York, USA, 13-42, 1991.

Raatz, W. E. and Shaw, G. E.: Long-range tropospheric transport of pollution aerosols in the Alaskan Arctic, J. Climate Appl. Meteor., 23, 1052-1064, 1984.

Schumann, U. and Huntrieser, H.: The global lightning-induced nitrogen oxides source, Atmos. Chem. Phys., 7, 3823-3907, 2007, http://www.atmos-chem-phys.net/7/3823/2007/.

Seiler, W. and Crutzen, P. J.: Estimates of gross and net fluxes of carbon between the biosphere and atmosphere from biomass burning, Clim. Change, 2, 207-247, 1980.

Shaw, G. E.: The Arctic haze phenomenon, B. Am. Meteorol. Soc., 76, 2403-2413, 1995.

Skamarock, W. C., Klemp, J. B., Dudhia, J., Gill, D. O. Baker, D. M., Duda, M. G., Huang, X., Wang, W., and Powers, J. G.: A description of the Advanced Research WRF version 3. NCAR Tech. Note NCAR/TN-475+STR, 113 pp., 2008.

Sprenger, M. and Wernli, H., A Northern Hemispheric climatology of cross-tropopause exchange for the ERA15 time period (19791993), J. Geophys. Res., 8521, doi:10.1029/2002JD002636, 2003.

Stohl, A. and Law, K., IGACtivities Newsletter, available online at: http://www.igac.noaa.gov/newsletter/igac33/May_2006_ IGAC_33.pdf, 33, 16-32, 2006.

Stohl, A.: Characteristics of atmospheric transport into the Arctic troposphere, J. Geophys Res., D11306, doi:1029/2005JD006888, 2006.

Stohl, A.: Computation, accuracy, and applications of trajectories A review and bibliography, Atmos. Environ., 32, 947-966, 1998.

Stohl, A., Eckhardt, S., Forster, C., James, P., and Spichtinger, N.: On the pathways and timescales of intercontinental air pollution transport, J. Geophys. Res. 107, 4684, doi:10.1029/2001JD001396, 2002.

Stohl, A., Forster C., Huntrieser H., Mannstein H., McMillan W. W., Petzold A., Schlager H., and Weinzierl, B.: Arctic smoke record high air pollution levels in the European Arctic due to agricultural fires in Eastern Europe, Atmos. Chem. Phys., 7, 913937, 2007, http://www.atmos-chem-phys.net/7/913/2007/.
Stohl, A., Wotawa, G., Seibert, P., and Kromp-Kolb, H.: Interpolation errors in wind fields as a function of spatial and temporal resolution and their impact on different types of kinematic trajectories, J. Appl. Meteorol., 34, 2149-2165, 1995.

Stohl, A., Hittenberger, M., and Wotawa, B.: Validation of the Lagrangian particle dispersion model FLEXPART against large scale tracer experiments, Atmos. Environ., 32, 4245-4264, 1998.

Stohl, A. and Thomson, D. J.: A density correction for Lagrangian particle dispersion models, Bound. Layer Met. 90, 155-167, 1999.

Stohl, A., Forster, C., Frank, A., Seibert, P., and Wotawa, G.: Technical Note: The Lagrangian particle dispersion model FLEXPART version 6.2, Atmos. Chem. Phys., 5, 2461-2474, 2005 , http://www.atmos-chem-phys.net/5/2461/2005/.

Wang, J., Christopher, S. A., Nair, U. S., Reid, J. S., Prins, E. M., Szykman, J., and Hand, J. L.: Mesoscale modeling of Central American smoke transport to the United States: 1. Top-down assessment of emission strength and diurnal variation impacts, J. Geophys. Res., 111, D05S17, doi:10.1029/2005JD006416, 2006.

Wang, J. and Christopher, S. A.: Mesoscale modeling of Central American smoke transport to the United States: 2. Smoke radiative impact on regional surface energy budget and boundary layer evolution, J. Geophys. Res., 111, D14S92, doi:10.1029/2005JD006720, 2006.

Warneke, C., Bahreini, R., Brioude, J., et al.: Biomass burning in Siberia and Kazakhstan as an important source for haze over the Alaskan Arctic in April 2008, Geophys. Res. Lett., 36, L02813, doi:10.1029/2008GL036194, 2009.

Williams, E. R.: The tripole structure of thunderstorms, J. Geophys. Res., 94, 13151-13167, 1989.

Wotawa, G., De Geer, L.-E., Becker, A., D’Amours, R., Jean, M., Servranckx, R., and Ungar, K.: Inter- and intra-continental transport of radioactive cesium released by boreal forest fires. Geophys. Res. Lett., 33, L12806, doi:10.1029/2006GL026206, 2006. 